\title{
Alcohol taxation and regulation in the European Union
}

\section{Sijbren Cnossen}

\begin{abstract}
This article surveys alcohol consumption, taxation and regulation in the European Union (EU). It uses the estimates of cost-of-illness studies to gauge the external costs of harmful alcohol use. In all but one member state, the costs exceed alcohol excise duty collections. An optimal alcohol excise is difficult to design, because the welfare gains from a reduction in socially costly heavy drinking must be balanced against the welfare loss from a fall in moderate drinking. This suggests that while an alcohol excise increase may be efficiency improving, complementary regulatory measures, which focus on specific problem groups, should be an important element of the policy package. A case can also be made for reducing wasteful crossborder shopping by raising the minimum duties on wine, beer and spirits, preferably in line with their relative alcohol content.
\end{abstract}

Keywords Alcohol taxation $\cdot$ European Union $\cdot$ External costs $\cdot$ Social costs

JEL Classification $\mathrm{H} 2 \cdot \mathrm{H} 8$

\section{Introduction}

Alcohol truly permeates every aspect of European culture; it is used before, during and after meals, to celebrate birth and mourn death, to socialize, as a relaxant, a deliriant and simply as a means of getting drunk. ${ }^{1}$ Adults in the European Union (EU) \footnotetext{
including beer, wine and spirits.

S. Cnossen $(\bowtie)$

Tapijtweg 7, 2597 KG The Hague, The Netherlands

e-mail: cnossen@few.eur.nl

S. Cnossen

CPB Netherlands Bureau for Economic Policy Analysis, Maastricht University,

Maastricht, The Netherlands
}

${ }^{1}$ Alcohol concerns ethyl alcohol, also known as ethanol, the type of alcohol found in drinks intended for human consumption. Throughout this paper, the term 'alcohol' covers all forms of alcoholic drinks, 
drink on average almost 13 liters of pure alcohol per year-two-and-a-half times the average for the rest of the world (WHO 2004). ${ }^{2}$ If abstainers are excluded, the consumption per drinker reaches 15 liters per year. This is equivalent to 600 half-liter bottles of beer, 167 bottles of wine or 54 bottles of spirits.

While one or two drinks per day seems to keep the doctor away, heavy drinking leads to violent behavior, causes accidents and has harmful effects on health (e.g. organ damage, birth defects). The World Health Organization (WHO 2005) has estimated that harmful consumption of alcoholic drinks is responsible for approximately $10.8 \%$ of the total disease burden in the EU. Following the WHO's methodology, Anderson and Baumberg (2006) estimate the total tangible costs (crime, health care, lost output) of alcohol to EU society in 2003 to be $€ 125$ billion, equivalent to $1.3 \%$ of GDP and four times the combined alcohol excise duty collections. The intangible costs in the form of pain, suffering and loss of healthy life are estimated to be more than twice the tangible costs.

The WHO views alcohol consumption, not just alcoholism, as a problem or illness. The cost-of-illness (COI) studies prepared by public health experts compute the tangible and intangible costs of harmful alcohol use, which they call social costs, as everything that happens that would not happen in a world without alcohol. Accordingly, the core of the WHO's 'health intervention policy' is 'to limit the harm caused by alcohol consumption, by reducing (or at least preventing from rising) the overall consumption per person' (Crooks 1989). Purportedly, this aim is to be achieved through taxes, regulations, subsidies, service provision and the dissemination of information.

The public health view contrasts sharply with the economic approach, adopted in this paper, which holds that alcohol is an ordinary commodity whose benefits should be considered along with its costs. Essentially, a rational, fully informed consumer should be allowed to drink whatever and as much as he likes as long as he does not bother other people. ${ }^{3,4}$ Under the consumer sovereignty principle, only the costs imposed on others, i.e. external costs, are relevant for policy analysis, not the private or internal costs borne by the drinker himself and presumably taken into account in the drinking decision. ${ }^{5}$ Moreover, the welfare costs of alcohol taxation and regulation imposed on moderate drinkers - 7 out of 10 adults in the EU-who do not cause

\footnotetext{
${ }^{2}$ Although the EU accounts for merely $7 \%$ of the world's population, it is the source of a quarter of the world's alcohol production-50\% more than either China or the US. France, Italy and Spain together produce half of the world's wine and Germany $7.5 \%$ of the world's beer, while the UK is the world's leading producer of whisky and gin, and Poland of vodka.

${ }^{3}$ The male pronoun is used advisedly since males are much more likely to engage in heavy drinking.

${ }^{4}$ Admittedly, the rationality condition ceases to apply if drinkers are ill-informed about the consequences of drinking (young people), act myopically in choosing to consume an addictive substance (Peck et al. 2000), or behave in a dynamically inconsistent fashion (Gruber and Koszegi 2001) by discounting costs and benefits in the near future to a greater extent than those in the long term. In the main, however, the rationality hypothesis continues to be the cornerstone of economic analysis.

${ }^{5}$ See also Bird and Wallace (2006), who discuss the differences between the public health approach and the economic approach. As the authors put it, if someone drinks too much and dies sooner than he or she otherwise would have done-for example, by crashing a motor vehicle while drunk-it may be a tragedy, but it is not an externality. If, however, the drunken driver kills a passer-by or a passenger, then it is both. In short, external costs (benefits) $=$ social costs (benefits) - private costs (benefits).
} 
externalities should be taken into account. The counterfactual world without alcohol is not relevant in evaluating real-world alcohol policy alternatives.

Under the economic approach, the purpose of the alcohol excise duty is to ensure that, at the margin, each drinker takes all external costs into account when making his drinking decision. This should induce him to drink his socially optimal quantity of alcohol. In setting the optimal tax rate, the challenge is that moderate drinking does not generate external costs, but heavy drinking does. Accordingly, there is a need to balance the reduction in harmful consumption through excise taxation against the loss in welfare of moderate or low-risk consumption. This means that calculating the optimal alcohol tax involves tradeoffs not encountered in a more standard case, such as a pollution tax (Pogue and Sgontz 1989; Kenkel 1996).

Against this background, this paper reviews alcohol consumption and taxation in the EU. Whether alcohol is taxed too low or too high would seem to depend on the level of and variation in the external costs of harmful alcohol use across member states. Section 2 sets the stage for the discussion by reviewing the current alcohol excise duties and collections in the various member states. Section 3 proceeds to examine alcohol consumption levels and patterns, as well as the effects of harmful alcohol use. Next, Sect. 4 uses estimates of various COI studies to infer the external costs. Subsequently, Sect. 5 attempts to draw inferences from the consumption patterns and the external costs about the properties of the optimal alcohol excise duty to see whether the current excise duties should be re-evaluated. Beyond taxation, alcohol regulation has a 'duty-equivalent' effect, so Sect. 6 examines the complementary role of regulations in restraining harmful alcohol consumption. Section 7 concludes with a summary of the implications of the analysis for alcohol tax and regulatory policies in the EU.

The paper does not dwell on the distributional impact of alcohol excise duties, because any undesirable tax burden effects can be offset by other tax (and expenditure) policies. The externality issues are what make alcohol excises of special interest.

\section{Excise duty structures and collections}

Excise duties on alcohol differ widely between EU member states. Harmonization measures have mostly been confined to product definitions (Directive 92/83/EEC) ${ }^{6}$ and agreement on minimum duties (with the target rates reduced to a non-binding note in the minutes). Excise duty collections from alcohol, per adult and per liter of pure alcohol, differ as widely between member states as the duties.

\footnotetext{
${ }^{6}$ There is no common definition in the EU of 'alcoholic drink' in terms of units of alcohol or \% alcohol by volume (abv). Legal definitions vary from $0.1 \%$ abv in Italy to $2.8 \%$ abv in Finland (WHO 2004); the EU average is $1.2 \%$ abv. The equivalence of different alcoholic drinks is measured in terms of units of alcohol. One unit is equal to approximately 10 grams of pure alcohol, often considered as one drink, since it is available from one shot glass of spirits $(30 \mathrm{ml})$, one rummer of wine $(120 \mathrm{ml})$ or one bottle of beer (285 ml).
} 


\subsection{Acquis communautaire $^{7}$}

The acquis communautaire for the principal alcoholic drinks, last agreed in 1992 (Directive 92/84/EEC), ${ }^{8}$ is the following.

- The minimum excise duty on beer is $€ 0.748$ per hl/degree Plato of finished product or $€ 1.87$ per hl/\% of alcohol by volume (abv). Accordingly, as a minimum, nearly 5 cents has to be paid in respect of half a liter of beer with an abv of $5 \%$ (equivalent to $12.5^{\circ}$ Plato) or more. Reduced rates apply to 'independent small breweries' and to 'low alcohol' beer (not exceeding $2.8 \%$ ).

- The harmonized excise duty on still and sparkling wine is $€ 0$ per hectoliter of product and so is the duty on fermented beverages other than wine and beer.

- On intermediate products, such as fortified wines and liqueur wines (below $22 \%$ abv and not belonging to the groups of wines or beer), the duty is $€ 45$ per hectoliter ( 34 cents per $75 \mathrm{cl}$ bottle); reduced rates apply to intermediate products not exceeding $15 \%$ by volume.

- The minimum excise duty on spirits (ethyl alcohol) is $€ 550$ or $€ 1,000$ per hectoliter of pure alcohol. ${ }^{9}$ In other words, the price of a $70 \mathrm{cl}$ bottle of spirits with an alcohol content of $40 \%$ includes excise duty of $€ 1.54$ or $€ 2.80$. Lower rates apply to 'small distilleries'.

- All alcoholic beverages are subject to the standard VAT rate, which cannot be less than $15 \%$.

- Indicative intra-EU duty-paid cross-border shopping allowances are 110 liters of beer, 90 liters of wine (but 60 liters of sparkling wine), 10 liters of spirits and 20 liters of intermediate products.

- The Council of Ministers has placed restrictions on the advertising of alcohol on television (Directive 89/552/EEC) and encouraged member states to address the problems caused by harmful alcohol use among young people (Recommendation 2001/458/EC). ${ }^{10}$

Of further interest are the rulings of the European Court of Justice (ECJ) on the non-discriminatory tax treatment of alcohol. The basic rule is that while member states have flexibility in setting the relative excise duties on alcoholic drinks, they cannot favor a domestic drink over a similar foreign drink. In the late 1970s and early 1980s, a number of discriminatory practices were forbidden, such as the tax-favored treatment of grape-based spirits (e.g. cognac) over grain-based spirits (e.g. whisky) by France and Italy, the relatively heavier taxation by alcohol content of wine over

\footnotetext{
${ }^{7}$ A French term that essentially means 'the EU as it is'-in other words, the rights and obligations that EU member states share. The 'acquis' includes all the EU's treaties and laws, declarations and resolutions, international agreements on EU affairs, and the judgments handed down by the European Court of Justice.

${ }^{8}$ On 8 September 2006, the European Commission (IP/06/1165) proposed increasing the minimum excise duties on beer to $€ 0.0612$ per half liter at $5 \%$ by volume (or $12.5^{\circ} \mathrm{Plato}$ ), on intermediate products to $€ 0.413$ per $70 \mathrm{cl}$ and on spirits to $€ 2.017$ per $70 \mathrm{cl}$ at $40 \%$. The harmonized duty on wine remains zero.

${ }^{9}$ The higher rate applies to Member States whose duty rate exceeded $€ 1,000$ in 1992.

${ }^{10}$ Although the EU seems to be concerned about the harmful use of alcohol, the production of wine is subsidized through the Common Agricultural Policy (CAP) at the rate of more than $€ 1.5$ billion each year in the EU-15. This protectionist policy has created a wine reservoir of almost 36 billion liters (1999-2000) in the EU-15 - twice the size of the total annual production (Elinder et al. 2003).
} 
beer in the UK, and the lower excise duty on aquavit relative to foreign spirits in Denmark. More recently, the Commission has taken Sweden to court over the higher excise duty on wine over beer of identical alcohol content (IP/04/1280). Furthermore, the ECJ has ruled that off-premise government-run alcohol monopolies are allowable but that exclusive import rights are not.

\subsection{Duty structures in Member States}

The acquis communautaire leaves considerable scope for significant tax differentials between member states for all types of alcoholic drinks. As shown in Table 1, beer, wine and spirits are particularly heavily taxed in Sweden, Ireland, the UK and Finland, but very lightly taxed in Luxembourg, Austria and the Mediterranean states, as well as most new Member States.

All alcohol excise duties are specific, although the precise specification of the tax base differs between beer, wine and spirits. In most member states, the excise on beer is proportional to alcohol content, but the Netherlands and Portugal graduate the duty, with higher rates of duty per hectoliter/degree Plato on stronger beer. The duty on spirits is defined uniformly throughout the EU in terms of an absolute amount per hectoliter of pure alcohol. By contrast, wine is taxed per unit volume, although in Denmark and Luxembourg the excise is banded according to the alcohol strength of the product.

Specifically, the excise duty on beer ranges from merely 4 cents per half liter in the Czech Republic, Germany, Luxembourg and Malta to almost $€ 1$ in Finland, Ireland and the UK. Thirteen member states do not levy an excise on still wine, but in Ireland, Sweden and the UK, the excise duty is close to $€ 2$ per $75 \mathrm{cl}$ bottle. Typically, sparkling wine is taxed at higher rates (not shown in the table) than still wine. The excise duties on spirits differ most widely in absolute amounts, ranging from $€ 1.71$ in Cyprus to $€ 15.08$ in Sweden per $70 \mathrm{cl}$ bottle.

Standard VAT rates that are applied to the excise-duty-inclusive prices of alcoholic drinks range from 15\% (Cyprus, Luxembourg) to 25\% (Denmark, Sweden); the EU average is $19.4 \%$. In this paper, the VAT is left out of consideration because the alcohol excise duty may be assumed to reflect the external cost of drinking. The imposition of VAT, therefore, does not affect the price of alcoholic drinks relative to other goods.

The right-hand side of Table 1 shows the relative excise duties on beer, wine and spirits calculated on the basis of alcohol content. As is well known, the medical profession measures the damage caused by harmful alcohol consumption in cubic centimeters of pure alcohol. A large volume of weak drinks is just as harmful as a smaller volume of strong drinks (Crooks 1989). On externality grounds, therefore, there appear to be good reasons to base the excises on alcohol content, but as Table 1 shows, on average, spirits are taxed twice as high as beer per unit of alcohol and five times more heavily than wine.

In general, little if any excise duty harmonization can be discerned in the EU. The agreed minimum rates have not been adjusted since 1992, implying a reduction in their real value of almost $30 \%$. In its last review of alcohol excise duty policies, the European Commission (2004) focused on the proper functioning of the internal 
Table 1 Alcohol excise duties in the European Union in 2006

\begin{tabular}{|c|c|c|c|c|c|c|c|}
\hline \multirow[t]{2}{*}{ Member state $^{\mathrm{a}}$} & \multicolumn{3}{|c|}{ Excise duties $(€)$} & \multirow[t]{2}{*}{$\begin{array}{l}\text { VAT } \\
(\%)\end{array}$} & \multicolumn{3}{|c|}{$\begin{array}{l}\text { Relative excise duties } \\
\text { by alcohol content }\end{array}$} \\
\hline & $\begin{array}{l}\text { Beer } \\
\text { per } 0.5 \text { liter }^{b}\end{array}$ & $\begin{array}{l}\text { Still wine } \\
\text { per } 75 \mathrm{cl}\end{array}$ & $\begin{array}{l}\text { Spirits } \\
\text { per } 70 \mathrm{cl}, 40 \%\end{array}$ & & $\begin{array}{l}\text { Beer } \\
5 \%\end{array}$ & $\begin{array}{l}\text { Still wine } \\
12 \%\end{array}$ & $\begin{array}{l}\text { Spirits } \\
40 \%\end{array}$ \\
\hline EU-15 & 0.33 & 0.58 & 5.36 & 19.8 & 53 & 21 & 100 \\
\hline Sweden & $0.79^{*}$ & 1.78 & 15.08 & 25 & 59 & 37 & 100 \\
\hline Ireland & $0.99^{*}$ & 2.05 & 10.99 & 21 & 101 & 58 & 100 \\
\hline UK & $0.95^{*}$ & 1.90 & 8.05 & 17.5 & 136 & 73 & 100 \\
\hline Finland & 0.97 & 1.59 & 7.91 & 22 & 138 & 63 & 100 \\
\hline Denmark $^{\mathrm{c}}$ & $0.34^{*}$ & 0.62 & 5.63 & 25 & 68 & 34 & 100 \\
\hline Belgium & 0.09 & 0.35 & 4.91 & 21 & 20 & 22 & 100 \\
\hline Netherlands & 0.13 & 0.44 & 4.21 & 19 & 33 & 33 & 100 \\
\hline France $^{\mathrm{d}}$ & $0.13^{*}$ & 0.03 & 4.06 & 19.6 & 36 & 2 & 100 \\
\hline Germany $^{\mathrm{e}}$ & 0.04 & 0.00 & 3.65 & 16 & 12 & 0 & 100 \\
\hline Greece & 0.06 & 0.00 & 3.05 & 19 & 21 & 0 & 100 \\
\hline Luxembourg ${ }^{\mathrm{f}}$ & 0.04 & 0.00 & 2.92 & 15 & 15 & 0 & 100 \\
\hline Austria & 0.10 & 0.00 & 2.80 & 20 & 40 & 0 & 100 \\
\hline Portugal & 0.08 & 0.00 & 2.62 & 21 & 35 & 0 & 100 \\
\hline Spain & 0.05 & 0.00 & 2.32 & 16 & 22 & 0 & 100 \\
\hline Italy & 0.12 & 0.00 & 2.24 & 20 & 59 & 0 & 100 \\
\hline EU-10 & 0.13 & 0.14 & 2.83 & 18.7 & 33 & 16 & 100 \\
\hline Malta & 0.04 & 0.00 & 6.52 & 18 & 6 & 0 & 100 \\
\hline Poland & 0.09 & 0.26 & 3.25 & 22 & 30 & 25 & 100 \\
\hline Estonia & $0.19^{*}$ & 0.50 & 2.72 & 18 & 76 & 57 & 100 \\
\hline Lithuania & $0.10^{*}$ & 0.33 & 2.59 & 18 & 44 & 39 & 100 \\
\hline Latvia & $0.09 *$ & 0.32 & 2.53 & 18 & 41 & 40 & 100 \\
\hline Czech Republic & 0.04 & 0.00 & 2.51 & 19 & 18 & 0 & 100 \\
\hline Hungary & 0.10 & 0.00 & 2.46 & 20 & 46 & 0 & 100 \\
\hline Slovak Republic & 0.06 & 0.00 & 2.04 & 19 & 35 & 0 & 100 \\
\hline Slovenia & $0.34^{*}$ & 0.00 & 1.95 & 20 & 20 & 0 & 100 \\
\hline Cyprus & $0.24^{*}$ & 0.00 & 1.71 & 15 & 16 & 0 & 100 \\
\hline EU-25 & 0.25 & 0.41 & 4.35 & 19.4 & 45 & 19 & 100 \\
\hline
\end{tabular}

\section{Sources}

Excise duties and VAT rates: European Commission, Excise Duty Tables, July 2006

Notes

${ }^{\text {a }}$ Ranked in descending order of duty on spirits

${ }^{\mathrm{b}} \mathrm{An}$ asterisk $\left(^{*}\right)$ indicates that the beer excise is levied per hl/\% of alcohol by volume (abv)

cDenmark levies an additional excise duty on 'mixed' alcoholic drinks, also called 'alcopops', of $€ 1.09$ ( $\leq 10 \%$ alcohol content) or $€ 1.98(>10 \%)$. The additional duty on mixed spirit drinks is $€ 0.39$ per liter ${ }^{\mathrm{d}}$ France levies an additional excise duty on 'alcopops' of $€ 110$ per liter of pure alcohol (equivalent to $€ 3.85$ per $70 \mathrm{cl}$ of $5 \%$ )

'Germany levies an additional excise duty on 'alcopops' of $€ 55.50$ per liter of pure alcohol (equivalent to $€ 1.94$ per $70 \mathrm{cl}$ of $5 \%$ )

f Luxembourg levies an additional excise duty on 'alcopops' of $€ 6$ per liter 
market in view of the wide divergences in duty levels, the competition between different categories of alcoholic drinks and the real value of the duty rates, and it paid lip-service to the wider objectives of the Treaty, i.e. underlying health, social and agricultural policies. Important practical issues, such as the extent of cross-border shopping and illicit production of spirits, were not touched upon. Basically, no action was taken.

\subsection{Excise duty collections}

As a percentage of total tax revenue, alcohol excise duty collections (Table 2) range from $0.2 \%$ in Italy to $2.5 \%$ in Poland and Ireland, a hard-drinking country (see Table 3) with high alcohol excise duties. Generally, alcohol excise duties are not a major source of revenue for the EU member states, except in Finland, Ireland, Poland and the UK. Alcohol excise duty collections are predominantly, although not exclusively, related to the level of the duties (see Table 1). On the other hand, there is no apparent correlation between the revenue from alcohol excise duties (as a percentage of government revenue or GDP) and per-adult consumption (see Table 3).

As shown in Table 2, in 2003, alcohol duty collections per adult ranged from a low of $€ 19$ in Italy to the extraordinarily high amount of $€ 318$ in Finland and Ireland. Five member states collected more than $€ 100$ per adult. While alcohol excise collections are significant in northern EU member states, they are of negligible proportions in southern states. The same picture emerges from a calculation of the absolute duty amounts that are paid per liter of recorded consumption of pure alcohol across member states. While Finns have to pay $€ 33$ per liter of pure alcohol, the Portuguese excise authorities are content with just over $€ 2$ per liter.

Particularly in high-duty member states, alcohol excise duty collections are affected by the extent of cross-border shopping and smuggling. Cross-border shopping is prevalent when there are large price differentials across small distances, such as the Öresund region (beer in Denmark costs merely $40 \%$ of the price in Sweden) and Helsinki-Talinn (spirits in Estonia cost a quarter of the price in Finland) (Karlsson and Tigerstedt 2005). Overall, at least 1 in 6 tourists in the EU returns from trips abroad with alcoholic drinks, carrying an average of over 2 liters of pure alcohol per person in several countries (Leifman 2001). In the UK, in 1998, cross-border shopping involved a revenue loss of $5 \%$ of total alcohol duty revenues (HM Customs and Excise 2004). ${ }^{11}$

Similarly, smuggling is a serious problem in the EU (European Commission 2004). For the EU-15, a High Level Group on Fraud in the Tobacco and Alcohol Sectors (1998) estimated that $€ 1.5$ billion revenue was lost to fraud in 1996 , equivalent to about $8 \%$ of total alcohol excise duty collections at that time. ${ }^{12}$ In the UK, smuggling is estimated to have deprived the Treasury of some $4 \%$ of total alcohol excise duty collections in 2001 (HM Customs and Excise 2004). ${ }^{13}$ Wells et al. (2005)

\footnotetext{
${ }^{11}$ See Christiansen and Smith (2001) and Crawford et al. (1999) for general treatments of cross-border shopping issues. Obviously, the incentives and effects of differential cross-border alcohol excise duties do not differ from those of duty-free shopping.

${ }^{12}$ It is unclear, however, how the estimate was derived.

${ }^{13}$ Interestingly, Huang (2003) calculates that the spirits duties in the UK could be raised by $40 \%$ before the maximum revenue is achieved, after allowing for the effect of cross-border shopping and smuggling.
} 
Table 2 Alcohol excise duty collections in the European Union in 2003

\begin{tabular}{|c|c|c|c|c|}
\hline Member state ${ }^{a}$ & $\begin{array}{l}\text { Collections } \\
\text { (€ billion) }\end{array}$ & $\begin{array}{l}\text { Collections as } \% \\
\text { of total tax } \\
\text { revenue }\end{array}$ & $\begin{array}{l}\text { Collections }(€) \text { per } \\
\text { adult (aged } 15+\text { ) }\end{array}$ & $\begin{array}{l}\text { Effective duty }(€) \text { per } \\
\text { liter of pure alcohol } \\
\text { consumed }\end{array}$ \\
\hline EU-15 & 25.9 & 0.8 & 101 & 10.4 \\
\hline Finland & 1.4 & 2.1 & 318 & 33.1 \\
\hline Ireland & 1.0 & 2.5 & 318 & 23.2 \\
\hline Sweden & 1.2 & 0.9 & 163 & 27.2 \\
\hline UK & 10.9 & 1.9 & 125 & 19.0 \\
\hline Denmark & 0.5 & 0.6 & 106 & 9.1 \\
\hline Luxembourg & - & 0.3 & 91 & 6.6 \\
\hline Belgium & 0.6 & 0.5 & 65 & 6.0 \\
\hline Netherlands & 0.8 & 0.5 & 64 & 6.6 \\
\hline France & 3.0 & 0.4 & 59 & 5.2 \\
\hline Germany & 3.7 & 0.5 & 52 & 4.3 \\
\hline Austria & 0.3 & 0.4 & 51 & 4.5 \\
\hline Greece & 0.3 & 0.6 & 33 & 3.6 \\
\hline Spain & 1.2 & 0.5 & 32 & 2.7 \\
\hline Portugal & 0.2 & 0.5 & 24 & 2.1 \\
\hline Italy & 0.9 & 0.2 & 19 & 2.4 \\
\hline EU-10 & . & - & 35 & 3.3 \\
\hline Malta & . & . & . & . \\
\hline Poland & 1.6 & 2.5 & 51 & 6.2 \\
\hline Estonia & . & . & . & . \\
\hline Lithuania & . & . & . & . \\
\hline Czech Republic & 0.3 & 1.0 & 34 & 2.7 \\
\hline Latvia & . & . & . & . \\
\hline Hungary & 0.2 & 0.8 & 29 & 2.1 \\
\hline Slovenia & . & . & . & . \\
\hline Slovak Republic & 0.2 & 0.7 & 24 & 2.3 \\
\hline Cyprus & . & . & . & . \\
\hline EU-25 & . & - & . & . \\
\hline
\end{tabular}

\section{Sources}

Excise duties and total tax revenues (excluding custom duties): OECD (2005) except for Spain and Portugal-European Commission, Excise Duty Tables, December 2003

Number of adults: Eurostat (people by age classes)

Consumption: Table 3 (recorded)

Note

${ }^{\text {a }}$ Ranked in descending order of excise duty collections per adult

believe that most of the illicit trade in alcohol occurs when drinks are illegally diverted from their (low-tax) claimed destination to a new (high-tax) one. 
Finally, it should be noted that, early on, the relatively higher taxation of alcohol (compared with other goods) has been defended by reference to the inverse elasticity rule (Ramsey 1927), which holds that other things being equal, efficiency losses from taxation are lower for goods with lower price elasticities of demand than for other goods with higher price elasticities of demand. Smith (2005), however, concludes that the reported price elasticities of alcohol demand are not so low that the inverse elasticity rule would seem to justify significantly higher-than-average taxation of alcohol.

\section{Alcohol use and effects}

To understand the nature and size of the social and external costs of harmful alcohol use, it is useful to briefly review the patterns, prevalence and effects of alcohol consumption. ${ }^{14}$

\subsection{Consumption patterns}

As Table 3 indicates, in 2003, EU adults (ages 15+) drank on average 12.6 liters of alcohol per year-with EU-10 adults (excluding Malta) drinking nearly 21/2 liters more than those in the EU-15. If adjusted for the number of adults (15\%) who abstain from alcohol, annual consumption reaches 15 liters. Although consumption levels have converged in the EU, there are still substantial differences between the two ends of the drinking spectrum. The Hungarians, for instance, drink 17.9 liters per adult per year, nearly three times as much as the Maltese. In recent years, recorded levels of consumption have declined or stabilized, perhaps on account of ageing populations and the increase in abstaining Muslims.

Just under half of all alcohol is consumed in the form of beer (44\%), with the rest divided between wine (33\%) and spirits (23\%). Although drink choices, like drink levels, are converging, typically beer is still the beverage of choice in northern Europe and wine in the Mediterranean states, while spirits consumption is heavily concentrated in central and eastern European countries. In addition to imbibing other forms of alcohol, the Czechs excel in beer drinking, downing 377 bottles (50 cl, 5\%) per adult every year, whereas the French win the wine contest with 93 bottles $(75 \mathrm{cl}$, $12 \%)$ and the Latvians the hard liquor drive with 25 bottles $(70 \mathrm{cl}, 40 \%)$ per adult (World Drink Trends 2004). By far the greatest proportion and level of expenditure on alcohol is found in Ireland, with each household spending $€ 1,942$ (5.5\% of household expenditures) on alcohol in 2001 (Strategic Task Force on Alcohol 2004). This is three times the level of any other country and over 10 times as much as Greece (Anderson and Baumberg 2006).

\footnotetext{
${ }^{14}$ Most of the studies on the use of alcohol and its impact on individuals and society are ably synthesized and reviewed in a formidable 432-page report by Anderson and Baumberg (2006), requested and financed by the European Commission. This paper draws on this report in sketching the wider effects and implications of harmful alcohol use as the background to a discussion of the tax and regulatory aspects of drinking.
} 


\subsection{Prevalence of alcohol use}

Alcohol has its abstainers, connoisseurs, harmful consumers and addictive users. Surveys on drinking habits tend to focus on particular problem groups so that policy measures can be tailored accordingly. Table 4 shows the amount of drink (in grams of pure alcohol per person per day) by which each group is defined (distinguishing between men and women) and the number of people in the EU estimated to belong to the various groups. ${ }^{15}$

About 53 million adults across the EU-some $15 \%$ of the adult populationabstain from alcohol, generally defined as not having had a drink in the past year. As shown in Table 3, abstention rates differ widely in the EU, partly due perhaps to the different measuring methodologies that were used. The large number of abstainers in Spain is noteworthy, as well as the fact that nearly every adult drinks in Denmark, Luxembourg and Germany. Interestingly, there is no correlation between total consumption and abstention rates, suggesting that drinkers and abstainers have little in common.

Table 3 Alcohol drinking patterns in the European Union in 2003

\begin{tabular}{|c|c|c|c|c|c|}
\hline \multirow{2}{*}{$\begin{array}{l}\text { Member } \\
\text { state }^{\mathrm{a}}\end{array}$} & \multirow{2}{*}{$\begin{array}{l}\text { Consumption } \\
\text { of pure alcohol } \\
\text { (liters per adult, } \\
\text { ages } 15+)^{b}\end{array}$} & \multicolumn{4}{|c|}{ Drinking prevalence } \\
\hline & & $\begin{array}{l}\text { Abstainers } \\
(\% \text { of } \\
\text { adults })^{\mathrm{c}}\end{array}$ & $\begin{array}{l}\text { Heavy } \\
\text { drinkers (\% } \\
\text { among } \\
\text { drinkers) }\end{array}$ & $\begin{array}{l}\text { Alcohol- } \\
\text { dependent } \\
\text { drinkers } \\
(\% \text { among } \\
\text { drinkers })^{\mathrm{e}}\end{array}$ & $\begin{array}{l}\text { Youth } \\
\text { drinking } \\
\text { (\% of } \\
\text { 15-year } \\
\text { olds) }{ }^{f}\end{array}$ \\
\hline EU-15 & 12.0 & & & & \\
\hline Ireland & 14.7 & 12.5 & 26.0 & . & 17.4 \\
\hline UK & 13.8 & 12.0 & 11.3 & 4.7 & 52.0 \\
\hline Denmark & 13.7 & 3.2 & 11.7 & 3.7 & 46.5 \\
\hline Germany & 13.0 & 5.1 & 11.2 & 3.8 & 39.3 \\
\hline Luxembourg & 12.8 & 2.5 & . & . & . \\
\hline Spain & 12.7 & 37.8 & 2.6 & . & 28.3 \\
\hline France & 12.4 & 6.7 & 12.2 & 8.7 & 16.9 \\
\hline Portugal & 12.4 & 15.5 & . & . & 15.5 \\
\hline Austria & 12.3 & 23.0 & 18.3 & 5.0 & 34.5 \\
\hline Finland & 11.7 & 7.4 & 4.6 & 4.0 & 16.8 \\
\hline Belgium & 11.4 & 18.9 & . & 7.0 & 39.2 \\
\hline Greece & 11.2 & 8.3 & 3.6 & . & 27.5 \\
\hline Netherlands & 10.2 & 15.8 & 14.2 & 5.5 & 51.4 \\
\hline Italy & 9.5 & 15.9 & 5.8 & 1.7 & 37.1 \\
\hline Sweden & 8.0 & 11.3 & 6.5 & . & 20.1 \\
\hline
\end{tabular}

\footnotetext{
${ }^{15}$ Anderson and Baumberg (2006) note that social surveys consistently under-record consumption of alcohol, because individual respondents consciously or unconsciously underestimate how much alcohol they consume (sometimes by as much as 40-60\%-IAS 2003) and because respondents reside primarily within private households and, hence, students and homeless people are excluded. 
Table 3 (Continued)

\begin{tabular}{|c|c|c|c|c|c|}
\hline \multirow{2}{*}{$\begin{array}{l}\text { Member } \\
\text { state }^{\mathrm{a}}\end{array}$} & \multirow{2}{*}{$\begin{array}{l}\text { Consumption } \\
\text { of pure alcohol } \\
\text { (liters per adult, } \\
\text { ages } 15+)^{b}\end{array}$} & \multicolumn{4}{|c|}{ Drinking prevalence } \\
\hline & & $\begin{array}{l}\text { Abstainers } \\
(\% \text { of } \\
\text { adults })^{\mathrm{c}}\end{array}$ & $\begin{array}{l}\text { Heavy } \\
\text { drinkers (\% } \\
\text { among } \\
\text { drinkers) }\end{array}$ & $\begin{array}{l}\text { Alcohol- } \\
\text { dependent } \\
\text { drinkers } \\
(\% \text { among } \\
{\text { drinkers })^{\mathrm{e}}}\end{array}$ & 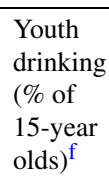 \\
\hline EU-10 & 13.6 & & & & \\
\hline Hungary & 17.9 & 6.4 & 12.4 & . & 24.4 \\
\hline Lithuania & 17.2 & 20.0 & 1.9 & . & 12.5 \\
\hline Latvia & 16.6 & 9.4 & 2.2 & . & 16.7 \\
\hline Slovak Rep. & 15.4 & 7.7 & 8.8 & 4.8 & 27.0 \\
\hline Czech Rep. & 14.0 & 11.9 & 19.1 & . & 28.9 \\
\hline Estonia & 12.8 & 7.5 & 1.7 & 1.4 & 23.7 \\
\hline Cyprus & 12.4 & 8.3 & . & . & 21.0 \\
\hline Slovenia & 12.3 & 14.5 & 13.0 & 11.0 & 34.3 \\
\hline Poland & 11.2 & 18.7 & 7.9 & 2.6 & 19.2 \\
\hline Malta & 6.3 & . & . & . & 47.3 \\
\hline EU average & 12.6 & & & & \\
\hline
\end{tabular}

\section{Sources}

Consumption—recorded: World Drink Trends (2004)

Unrecorded consumption and drinking prevalences: WHO, Country Profiles (2004), downloaded from www.eurocare.org/btg/countryreports/index.html (6 August 2006)

\section{Notes}

${ }^{\text {a }}$ Ranked in descending order of per-adult alcohol consumption

${ }^{b}$ Including unrecorded consumption (alcohol that comes from smuggling, home production and crossborder shopping as well as failing to adjust for drinks bought by tourists rather than residents): Malta0.3 liter; Belgium, Netherlands-0.5 liter; Austria, Cyprus, Czech Republic, France, Germany, Ireland, Portugal, Spain -1 liter; Slovenia-1.3 liters; Italy-1.5 liters; Denmark, Greece, Sweden, UK-2 liters; Finland-2.1 liters; Poland-3 liters; Hungary-4 liters; Lithuania-4.9 liters; Estonia, Slovak Republic5 liters; Latvia - 7 liters. Luxembourg's unrecorded consumption is -1 liter due to tourist shopping

${ }^{c}$ Generally, abstainers are defined as adults who had not been drinking in the year before the survey, but other definitions are used in Austria and Ireland. In Latvia, Malta and Spain, only lifetime abstainers are included

${ }^{\mathrm{d}}$ Generally, heavy drinking is defined as average consumption of 40-60 $\mathrm{g}$ of pure alcohol per day for men and 20-40 g or more for women (30 g and $20 \mathrm{~g}$ respectively in Sweden), but different definitions are used in Denmark, Greece, Ireland, Lithuania, the Netherlands, Poland and Slovakia

${ }^{\mathrm{e}}$ Generally, alcohol dependence is defined as average consumption of $60 \mathrm{~g}$ or more of pure alcohol per day for men and more than $40 \mathrm{~g}$ for women, but many countries use other criteria

${ }^{\mathrm{f}}$ Youth drinking is generally defined as the proportion of 15-year-olds who report drinking beer, wine or spirits at least weekly. Cyprus defines it as lifetime use of 40 times or more

Seven in 10 people in the EU are moderate or low-risk drinkers. ${ }^{16}$ For them, the use of alcohol brings with it various psychological benefits, such as stress reduction,

\footnotetext{
${ }^{16}$ Note that moderate drinking is defined as up to four drinks per man per day and up to two per woman per day-twice the level that is regarded as not interfering with a healthy lifestyle.
} 
Table 4 Drinking levels in the European Union, 2001 estimates

\begin{tabular}{lllll}
\hline $\begin{array}{l}\text { Drinking } \\
\text { levels }\end{array}$ & Description & $\begin{array}{l}\text { Definition } \\
\text { (g alcohol/day) }\end{array}$ & Adults (16+) \\
\cline { 3 - 4 } & & Men & Women & EU-25 (million) \\
\hline Abstinent & & 0 & 0 & 53 \\
Level I & Moderate or low-risk drinkers & $>0-40$ & $>0-20$ & 263 \\
Level II & Heavy, hazardous or excessive drinkers & $>40-60$ & $>20-40$ & 36 \\
Level III & Alcohol-dependent or addictive drinkers & $>60$ & $>40$ & 22 \\
\hline
\end{tabular}

Source

Anderson and Baumberg (2006). The classification is based on Rehm et al. (2004)

mood elevation, increased sociability and relaxation (Peele and Brodsky 2000). Moderate alcohol use (at $20 \mathrm{~g}$ of alcohol, or two drinks, per day), moreover, decreases the risk of coronary heart disease by up to $80 \%$ from the level of non-drinkers (Corrao et al. 2000). ${ }^{17}$ Drinking in middle age appears to extend life expectancy overall (NIAAA 2000), but the effect is particularly pronounced for women who die after the age of 70 (White et al. 2002). Also, alcohol seems to reduce the risk of type II diabetes and gallstones.

Approximately 58 million EU adults (15\%, about the same number as the population of the UK) 'drink too much', generally defined as more than $40 \mathrm{~g}$ of pure alcohol (more than four drinks) for men and more than $20 \mathrm{~g}$ (more than two drinks) for women (Babor et al. 2003). Of this number, 36 million people are heavy drinkers and 22 million alcohol-dependent drinkers (5\% of men, $1 \%$ of women). Heavy and alcohol-dependent drinking is particularly prevalent (more than $20 \%$ of drinkers) in Austria, France, Ireland and Slovenia (Table 3). ${ }^{18}$ No doubt most EU-10 member states would be added to this list if reliable information were available.

Various researchers have assumed harmful alcohol use to coincide with binge drinking, i.e. drinking to intoxication by downing 2.8 liters of beer, a bottle of wine or five shots of spirits on a single occasion. Across the EU-15, adults report getting drunk five times per year on average but binge-drinking 17 times (Eurobarometer 2003). The same source reports 40 million EU-15 citizens 'drinking too much' and 100 million (more than 1 in 4) binge-drinking at least once per month.

Alcohol dependence among the EU population, measured as having four positive $\mathrm{CAGE}^{19}$ answers, is 5\% or higher in Austria, Belgium, France, the Netherlands and

\footnotetext{
${ }^{17}$ In the EU, the death of some 160,000 people is believed to be delayed due to the beneficial effects of moderate drinking (Anderson and Baumberg 2006). However, for a view that one drink a day won't keep the doctor away, particularly in European drinking cultures, see Lieber (2003). And for a view that the beneficial health effects of moderate drinking can more easily be obtained through other means, see Barker (2002).

${ }^{18}$ The Czech Republic and the Netherlands come close to the $20 \%$ level. According to Rehn et al. (2001), the figures on heavy drinking that stand out most clearly from the WHO statistics are the number of women $(21 \%)$ in Ireland drinking more than $140 \mathrm{~g}$ of alcohol per week, the number of men $(29 \%)$ in Austria exceeding $420 \mathrm{~g}$ per week and the number of men in the Czech Republic (16\%) exceeding $550 \mathrm{~g}$ per week. As noted above, $10 \mathrm{~g}$ of alcohol represents one drink.

${ }^{19}$ According to the CAGE (Cut, Annoyed, Guilty, Eye-opener) test, an individual is considered a problem drinker if he or she answers positive to one or more of the following questions: (a) have you ever felt 
Slovenia (Table 3). Some studies have suggested that the proportion of heritability of alcohol dependence is between 50\% and 60\% (Cook and Gurling 2001). Alcohol dependence is particularly common among young adults (Caetano and Cunradi 2002).

\subsection{Youth drinking}

The foundations for harmful alcohol use are laid in childhood and adolescence. In 17 member states, the proportion of 15-year-olds who report drinking beer, wine or spirits at least weekly is $20 \%$ or higher (Table 3). In Denmark, Malta, the Netherlands and the UK, approximately half of 15-year-olds drink weekly. Over 1 in 8 (13\%) of 15- to 16-year-old students have been drunk more than 20 times in their life, and more than 1 in $6(18 \%)$ have binged $(5+$ drinks on a single occasion) three or more times in the last month (Hibell et al. 2004). Frequent drinking at ages 14-15 years predicts alcohol dependence at ages 20-21 years (Bonomo et al. 2004). But the habit starts at a much younger age. In most member states, more than $50 \%$ of 11 -year-olds have already tried alcohol at least once (Settertobulte et al. 2001) and 12\% of this age-group reports having been drunk twice or more.

As Cook and Moore (2002) point out, teenagers and young adults are of special concern for at least three reasons. First, youths exhibit relatively high rates (compared with elders) of binge drinking and involvement in violent crime and motor vehicle accidents. ${ }^{20}$ Second, to the extent that drinking is habit forming, youthful drinking sets the patterns for future consumption. Third, drinking behavior during the transition from adolescence to adulthood may have deleterious consequences for human capital and family formation.

\subsection{Consequences of harmful alcohol use}

The (predictable) consequences of harmful alcohol use show up in statistics on alcohol-related fetal damage and child abuse, marital harm, road traffic accidents, crime and violence, increased mortality and some 60 alcohol-related diseases and conditions. Table 5 provides a synopsis of the conclusions of various recent studies on the effects of harmful alcohol use. Although it should be emphasized that 'related' does not necessarily imply 'causality', clearly, harmful alcohol use has dire effects on people's well-being in the EU, particularly people other than the drinkers themselves.

\section{Social and external costs of harmful alcohol use}

The social (private plus external) costs of harmful alcohol use have been estimated for several member states, but there are no studies for the EU that focus exclusively

\footnotetext{
you ought to cut down on your drinking? (b) have people ever annoyed you by criticizing your drinking? (c) have you ever felt bad or guilty about your drinking? (d) have you ever had a drink first thing in the morning to steady your nerves or get rid of a hangover ('eye opener')? Similar questions are raised under the Alcohol Use Disorders Identification Test (Audit) and the Severity of Alcohol Dependence Questionnaire (SAD-Q). See UK Cabinet Office (2003) for further definitions.

${ }^{20}$ Matthews and Richardson (2005) report that in the UK, $24 \%$ of all violent offences are committed by 18 - to 24 -year-old binge drinkers, compared with $16 \%$ by other regular drinkers and $5 \%$ by occasional drinkers or non-drinkers of the same age.
} 
Table 5 Studies on the costs of harmful alcohol use in the European Union

\begin{tabular}{lll}
\hline Author(s) & Year & Content of study findings \\
\hline
\end{tabular}

\section{A. Harm to children}

WHO

Hibell et al.

Anderson and

Baumberg

English et al. +

Ridolfo and Stevenson

\section{B. Drink-driving}

WHO

WHO

ETSC

\section{Crime and violence}

Rossow, Pernanen, and Rehm

WHO

Anderson and

Baumberg

Mirrlees-Black +

Watson and Parsons

\section{Mortality and health}

Rehn, Room, and

Edwards

Rehn, Room, and

Edwards

WHO

Alcohol is the third-leading risk factor (out of 26 risk factors for ill health) for death and disability in the EU, ahead of obesity/overweight and nearly four times that of illicit drugs

2001 Alcohol causes nearly 260,000 deaths each year, equivalent to $6 \%$ of all male deaths and $2.5 \%$ of all female deaths

2004 Cancers are the largest single cause of alcohol-attributable deaths, accounting for 50,000 deaths each year, followed by 45,000 deaths through cirrhosis of the liver and 17,000 deaths due to neuropsychiatric conditions

\section{E. Work}

Ramstedt and Hope
2003 Across seven EU-15 member states, nearly 5\% of drinking men and $2 \%$ of drinking women reported a negative impact of alcohol on their work or studies 
on the external costs. Accordingly, an attempt is made to infer the size of these costs from the social cost studies.

\subsection{Social costs of harmful alcohol use in Europe}

In recent years, various individual EU member states, at the instigation of the World Health Organization, have published comprehensive estimates of the costs of alcohol-attributable output losses, criminal offenses and hospitalizations. Anderson and Baumberg (2006) use these and other existing member-state-level studies-21 in all (with a further nine international studies used for sensitivity analyses) — to estimate the social costs of harmful alcohol use for the EU as whole. ${ }^{21}$ The authors make a distinction between tangible (economic) costs and intangible (pain and lossof-healthy-life) costs. Tangible costs are subdivided into (a) direct costs: health care (including treatment and prevention), crime (police, defensive, property damage) and traffic accidents damage, and (b) productivity losses: absenteeism, unemployment and mortality (including traffic deaths).

As shown in Fig. 1, Anderson and Baumberg (2006) estimate the total tangible cost of alcohol to EU society in 2003 to be $€ 125$ billion (based on minimum and maximum estimates ranging from $€ 79$ billion to $€ 220$ billion), equivalent to $1.3 \%$ of GDP, which is roughly the same as that found recently for tobacco (Aspect Consortium 2004). ${ }^{22}$ Actual spending on alcohol-related problems, i.e. direct costs, accounts for $€ 66$ billion of the total tangible costs. The remaining $€ 59$ billion represents productivity losses.

Fig. 1 Tangible social costs of alcohol in the European Union in 2003. Source: Anderson and Baumberg (2006)

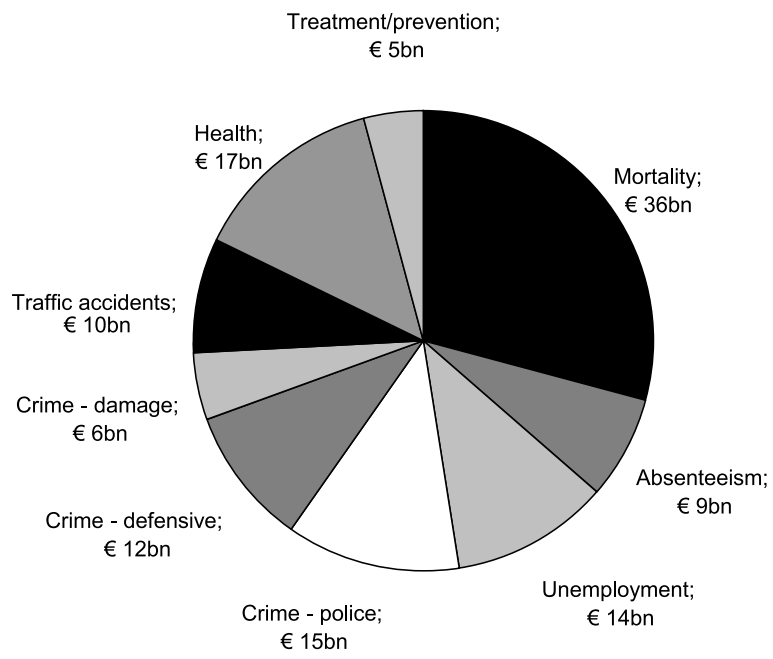

\footnotetext{
${ }^{21}$ Anderson and Baumberg's (2006) review applies strict methodological standards-for several cost components, only a small number of studies passed the methodological standards-largely based upon the WHO Guidelines on Estimating the Costs of Substance Abuse (Single et al. 2003).

${ }^{22}$ Generally, much of the external cost of alcohol misuse is borne by victims of intoxicated consumers. By way of contrast, most smoking-related costs, including morbidity and early death, are borne by the smokers themselves.
} 
The intangible costs (not included in Fig. 1) represent the value people place on pain, suffering and loss of healthy life that occur because of the criminal, social and health harms caused by alcohol. Anderson and Baumberg (2006) estimated these costs to be $€ 270$ billion (range $€ 150-€ 760$ billion) in 2003 . As the authors point out, this estimate is subject to a wide range of error, as found for all COI studies. ${ }^{23}$ Ninety-five percent of the intangible costs represent the value of the loss of healthy life - calculated on the basis of Disability-Adjusted Life Years (DALYs) which mainly but not exclusively lies with the drinker. ${ }^{24}$

\subsection{External costs in individual member states}

From an economic point of view, the problem with the COI studies is that they use a framework that draws an insufficiently clear distinction between private and external costs. (The key issue-whether the costs are internal or external-cuts across the socalled tangible and intangible costs.) Particularly contentious are the high estimates for the loss of healthy life, the emotional impact costs for victims of crime, and various other psychosocial and behavioral effects. These estimates are a multiple of the direct tangible costs and are sensitive to the rate of discount that has been used in converting lifetime costs into present costs. Importantly for external cost studies, these estimates do not distinguish between the loss of healthy life of the drinker (private costs) and that of the victim (external cost). Furthermore, cost savings (premature death of non-working people, health-care costs of other more costly diseases ${ }^{25}$ ) are not considered.

From an external cost point of view, doubts can also be raised about the value of the loss of output due to reduced employment. As Smith (2005) points out, how far the productivity effect of employees' harmful alcohol use is reflected in individual wages (no externality), and how far it is collectively borne (payments of social benefits), is unclear. ${ }^{26}$ Neither are tax revenue externalities taken into account. After all, the loss in taxed wages is partly shared by society and hence is not a matter of social

\footnotetext{
${ }^{23}$ As Single and Easton (2001) sum up succinctly, the social cost studies of harmful alcohol use are plagued by a lack of consensus regarding the appropriate methodology to be used, the lack of (reliable) information, the use of a layering of multiple assumptions, changes in the epidemiological database, and what we know about the effects of alcohol use. As (Maynard et al. 1994) note: "When policy makers are given such studies, they should be aware that they come with a government health warning: naive use of such data can damage the Nation's health!"

${ }^{24}$ Except, perhaps, for the intangible costs of alcohol dependence to family members and victims of crime, which are reported to be $25 \%$ of the total. Intra-family effects are sometimes left out of consideration because it is assumed that the welfare of the family enters the utility function of the alcohol consumer. In the case of alcohol abuse, this seems implausible, however, and the costs of domestic violence and injuries, particularly if inflicted on young and unborn children, would seem best treated as externalities (Smith 2005).

${ }^{25}$ Obviously, this does not mean that death is an economically desirable event. Rather, as Warner et al. (1995) point out, it simply means that as long as early death reduces the extra social costs in the form of social benefits and pensions, drinkers should receive a 'credit' for the associated savings.

${ }^{26}$ It should be pointed out that COI studies do not include social benefits (which are considered a transfer) in their social cost calculations, while external cost studies do include these benefits (because they are a cost to society).
} 
indifference. Beyond that, the drinker clearly faces most of the costs of premature mortality.

Evidence in the US context shows that the direct effect of drinking on productivity is small-in fact, self-reported abstainers earn less, on average, than drinkers (Cook and Moore 2002). Indeed, MacDonald and Shields (2001) report an inverse U-shaped relationship between drinking intensity and mean hourly wages. The turning points for the inverted U-shaped curve are in the ranges 21-36 units per month for men and 14-28 units for women. ${ }^{27}$ Furthermore, if harmful alcohol use results in unemployment or early death, the basic underlying assumption of the COI studies is that the loss of output is irreplaceable by other people without jobs. When a Danish study (Sundhedsministeriet 1999) assumed that the unemployed would be replaced after 3 months, it concluded, on this basis, that the figure for loss of output was 100 times lower than the corresponding COI study's estimate.

On the basis of these considerations, this paper examines Anderson and Baumberg's (2006) review of the COI-studies for individual member states to see whether there is some minimum of external costs which can be confronted with the amount of excise duty collections. Clearly, nearly all of the direct tangible costs (health care, crime, traffic accidents) would qualify as external costs. In all likelihood, these direct costs are lower than the actual external cost, because they do not include the value of the life of non-drinkers lost in alcohol-related crime and traffic accidents, nor various social benefit payments. With some justification, therefore, the direct costs can be considered the lower bound of the external costs. The upper bound includes tangible costs (production losses) on account of absenteeism, unemployment and premature mortality, although, arguably, not all of these costs should be considered external costs (while other items, such as social benefits, should be added). Intangible costs are left out of consideration entirely, although, again, not all of these costs are private costs. This rough-and-ready approximation yields some insight in evaluating alcohol taxation and regulation policies. ${ }^{28}$

On this basis, Table 6 presents the external costs of harmful alcohol use in $11 \mathrm{EU}$ 15 member states, as well as four other countries with drinking patterns and problems similar to those in northern Europe. The table indicates that the lower bound of the external costs of harmful alcohol use-on average about $0.7 \%$ of GDP - is remarkably similar across the member states, although external costs in northern member states tend to be somewhat higher than those in southern member states. Furthermore, the average lower bound of the external costs (excluding the outliers Portugal and Belgium) is $€ 217$ per adult, ranging from $€ 123$ in Spain to $€ 354$ in Ireland. Similarly, the average lower bound of the external costs per liter of pure alcohol is $€ 17$ ( $€ 10$ in Spain to $€ 24$ in Ireland).

These figures can be confronted with the alcohol excise duty collections per adult and the effective duty per liter of pure alcohol shown in Table 2. The comparison

\footnotetext{
${ }^{27}$ Cook and Moore (2002) note, however, that there is persuasive evidence that heavy drinking has an indirect effect on productivity by interfering with schooling and family formation, both of which affect subsequent productivity and earnings.

${ }^{28}$ For a review and critique of social cost studies and some differences with external cost studies, see Maynard et al. (1994). The following analysis is confined to the implications of the lower bound of the external costs for alcohol excise policy; the upper bound is not discussed further.
} 


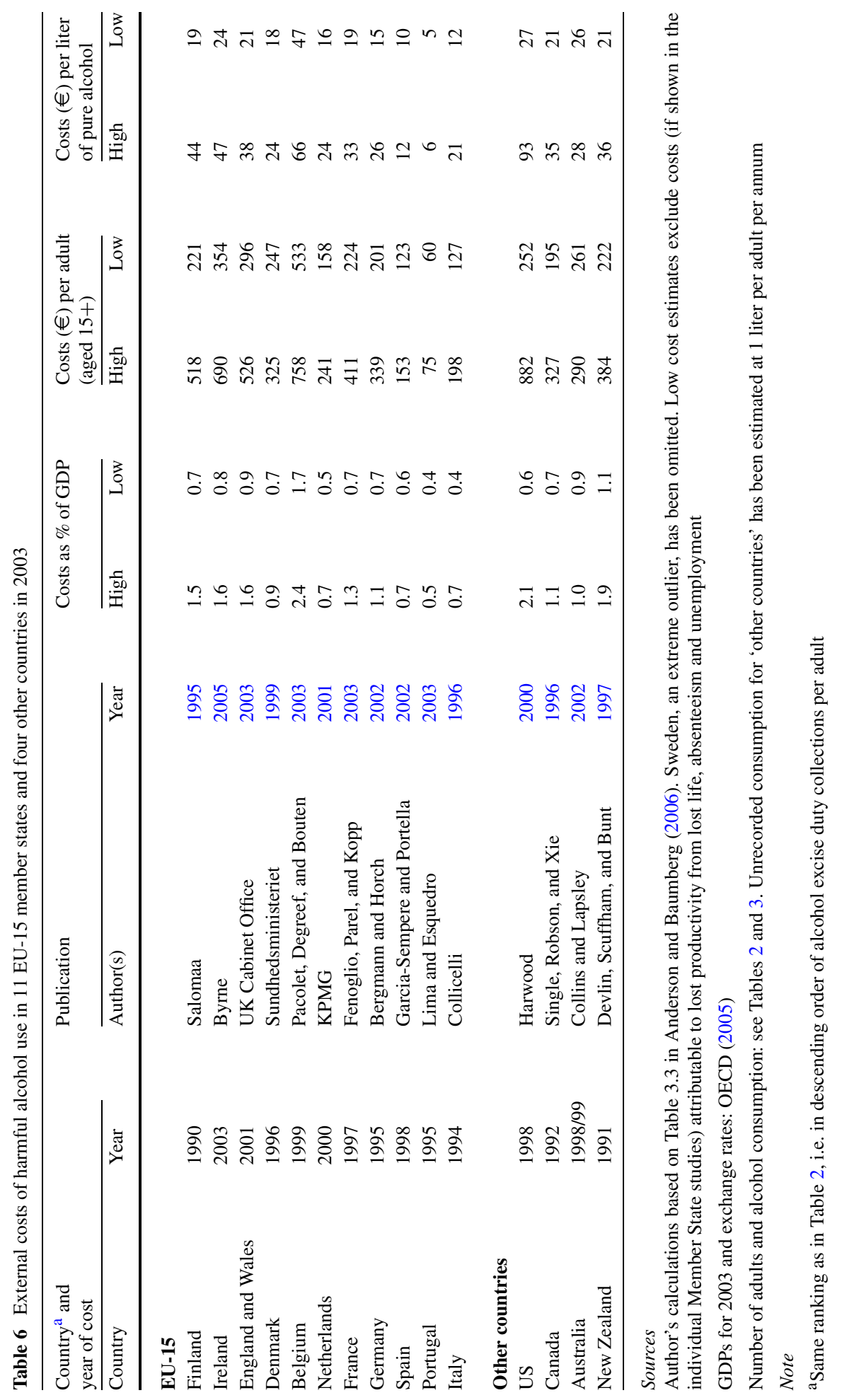


indicates that Finland is the only member state in which the collections and the effective duty exceed the lower bound of the external costs shown in Table 6. Ireland comes close to this benchmark (England and Wales to the effective duty criterion), but in all other member states, the external costs per adult and per liter of pure alcohol exceed the excise collections and the effective duty rate, respectively, by a wide margin. Table 6 also shows the external costs of harmful alcohol use in the US, Canada, Australia and New Zealand. The lower bounds of the cost estimates are in line with those calculated for northern EU member states.

A tentative conclusion of these results is that the alcohol excise collections do not pay for the (lower bound) external costs of harmful alcohol use, i.e., health care, treatment/prevention, criminal justice system, property damage and traffic accidents damage. This finding seems to be in line with the results of various US studies, which explicitly calculate the external costs of harmful alcohol use. In a pioneering study, Manning et al. (1989) estimated the net external costs in the mid-1980s at about US $\$ 0.48$ per ounce of ethanol, double the average state and federal tax per ounce that was then in place. A similar result was reported by Pogue and Sgontz (1989). Much of the external costs were borne by victims of drunk drivers. The costs would have been higher still had non-fatal highway injuries (Miller and Blincoe 1994) and intra-family effects been taken into account. Furthermore, Kenkel (1996) estimated that the duty rate should be about equal to the pre-tax alcohol price, while Saffer and Chaloupka (1994) calculated the weighted average optimal US tax on alcohol at 2.3 times the 1991 level.

\subsection{UK Cabinet Office study}

To appreciate the intricacies and complexities of social (and external) cost studies, it seems useful to look more closely at a sophisticated recent UK COI study (UK Cabinet Office 2003), which provides estimates of prevalence-based alcohol misuse in England and Wales in 2001 over a range of alcohol-dependent drinkers $(7.9 \%$ of the English population aged 16 and over) and heavy drinkers (5.4\% of the population). ${ }^{29}$ Table 7 shows the cost estimates under three broad headings: direct tangible costs (crime, health care), tangible costs in the form of loss of productive output, and intangible costs (pain, suffering, premature death). ${ }^{30}$

Almost two-fifths of the total social costs are accounted for by the valuation of alcohol-related crime and health care. Following Brand and Price (2000), the study distinguishes three categories of alcohol-related crime costs: (a) costs incurred in anticipation of crime (excluding insurance premiums, which are not an opportunity cost, although the cost of insurance administration is); (b) costs incurred as a consequence

\footnotetext{
${ }^{29}$ These figures differ from those in Table 3 mainly due to the use of different definitions. Incidentally, the UK government's sensible drinking message is 3-4 units per day for men and 2-3 for women. By this measure, $39 \%$ of men and $21 \%$ of women exceeded the weekly recommended levels in 2000-2001. For the sensible drinking message, see www.dh.gov.uk/PolicyAndGuidance/HealthAndSocialCareTopics/ AlcoholMisuse/AlcoholMisuseGeneralInformation/AlcoholMisuseGeneralArticle/fs/en?CONTENT_ID= 4062199\\&chk=J782BY.

${ }^{30}$ The figures have been rearranged into tangible and intangible costs to fit the approach adopted in this paper. A similar study was done for Scotland (Scottish Executive Health Department 2003), but the results are not directly comparable and therefore have not been added.
} 
Table 7 Social costs of harmful alcohol use in England and Wales in 2001

\begin{tabular}{lll}
\hline Category of cost & $\begin{array}{l}€ \text { million } \\
(£ 1=€ 1.47)\end{array}$ & $\begin{array}{l}\% \text { of pre-excise } \\
\text { alcohol } \\
\text { expenditure }\end{array}$ \\
\hline
\end{tabular}

\section{A. Tangible costs-direct}

Alcohol-related and alcohol-specific crime

Criminal justice system costs

Property/health and victim services

Costs in anticipation of crime (alarms, etc.)

Drink-driving offences

(Criminal justice system costs

(Medical and ambulance

\section{Health care}

Hospital in-patient visits

Hospital out-patient visits

Accident and emergency visits

Ambulance services

Nurse and GP consultations

Specialist treatment services

Other health-care costs

\section{B. Tangible costs-lost output}

Drinkers

Absenteeism

Reduced employment

Reduced employment efficiency

Third parties

Victims of crime

Victims of drink-driving

\section{Intangible costs}

Emotional impact costs for victims of crime

Human costs of drink-driving

Premature death of drinkers (lost output)

D. Total including lost output and intangible costs

E. Total excluding intangible costs

F. Total excluding lost output and intangible costs

G. Pre-excise expenditure on alcoholic drinks Excise duties [VAT

\section{1,075}

28.7

8,609

22.3

2,565

3,695

2,190

159

113)

46)

2,466

771

653

447

300

100

141

54

7,281

18.9

5,773

15.0

2,617

3,156

1,508

3.9

1,421

87

11,017

6,857

523

3,637

29,373

76.2

18,356

47.6

11,075

28.7

38,569

8,984

23.3

Sources

Social costs: UK Cabinet Office (2003), Second Estimate

Expenditure on alcoholic drinks: IAS (2003)

Excise duty and VAT collections: OECD (2005)

Figures on expenditure and tax collections were adjusted for England and Wales on a population basis 
of crime (cost of property damaged or stolen, victim support) ${ }^{31}$ and (c) costs incurred in response to crime (costs to the criminal justice system). The costs of drink-driving offences are shown separately. In 2000, 6\% of all road accidents and $16 \%$ of road deaths in England and Wales were caused when someone was driving over the legal limit for alcohol.

The health-care costs of harmful alcohol use were estimated through the use of 'attribution fractions' based on previously established research findings. In most EU member states, health-care costs are largely financed through quasi-tax contributions. Accordingly, health-care costs are an important part of external costs, and, other things being equal, the optimal rate of alcohol taxation should be higher in these member states than in countries, such as the US, where health insurance premiums are effectively differentiated to reflect individual risks. ${ }^{32}$

The costs of harmful alcohol use associated with the workplace and the wider economy are extremely difficult to estimate. The UK Cabinet Office (2003) focuses on two types of costs related to reduced output: (a) employee absenteeism (alcohol misuse increases the average number of days of sickness); and (b) unemployment and lower activity rates through a 'discouraged worker' effect (MacDonald and Shields 2001). This paper adds the figures for the valuation of the lost output for the victims of crime and drink-driving. As Table 7 indicates, social costs under this heading represent close to a quarter of total costs. These costs should not be considered external costs to the extent that they are reflected in lower wages or the affected employees are replaced (although the associated social benefits should be included under external costs).

The UK Cabinet Office (2003) also estimates the value of emotional impact costs for victims of crime, the human costs of drink-driving and the lost output due to premature mortality as a result of harmful alcohol use. As Table 7 shows, these intangible costs are as large as the direct tangible costs. The human costs of alcohol-related social and physical harm are also discussed, but no attempt is made to quantify them, although the study makes clear that harmful alcohol use has dire effects on family life (children are often the main victims).

The UK Cabinet Office's study (2003) repeatedly points out that the social costs of harmful alcohol use are difficult to conceptualize and quantify, if only because of the uncertainty regarding the causality between harmful alcohol use and its negative consequences. This is especially true for the value of lost output and the intangible costs. Although these two categories of social costs should not be dismissed too lightly, for expository purposes Table 7 makes a distinction between the social costs with and without these costs. On this basis, the total social costs of harmful alcohol use

\footnotetext{
${ }^{31}$ In addition, Brand and Price (2000) and UK Cabinet Office (2003) also classify the loss of productive output of the direct victim and the emotional impact costs under the heading 'alcohol-related and alcohol-specific crime', but this paper puts these costs under the heading 'tangible costs-lost output' and 'intangible costs', respectively.

${ }^{32}$ Although premiums might not be formally charged at different rates to harmful alcohol users, the fact that premiums are partly experience rated (those who claim more face higher premiums in future years), combined with the fact that a significant part of alcohol damage is short term and more immediate, will together have the effect of making harmful users bear a fair proportion of their health-care costs through higher premiums.
} 
(including lost output and intangible costs) amount to three-quarters of pre-tax expenditure on alcoholic beverages or more than three times total excise duty collections. If intangible costs are excluded, the social costs are nearly half of pre-tax expenditure on alcoholic drinks or twice the amount of excise duty revenues. As above, this may be called the upper bound of the external costs. The lower bound is found by also excluding the value of lost output. As can be seen, excise duty collections still fall short of external costs.

\section{Optimal alcohol excise duty}

Since drinkers have different demand or cost functions, different optimal duties should be imposed on them. Obviously, this cannot be done at acceptable cost, and the optimal uniform Pigouvian alcohol excise duty, therefore, would have to be a weighted average of each drinker's non-uniform optimal duty-the weights being each drinker's standardized price derivative of demand. ${ }^{33}$ Again, information for calculating this uniform optimal excise duty is not available, but, as Pogue and Sgontz (1989) as well as Barker (2002) note, the appropriate level of the duty can be inferred from information on drinking patterns (Sect. 3), the level and pattern of the external costs (Sect. 4), the shape of the damage function of alcohol consumption and the price responsiveness of drinkers. This should permit an approximate assessment of the balance between the gain from a reduction in total external costs and the loss in consumption benefits that is not regained as excise revenue.

\subsection{Shape of the alcohol damage function}

As shown in Sect. 3, the externalities of alcohol consumption are dominated by harm from binge drinking, also called acute consumption. In the EU, the top $10 \%$ of the drinking population drinks between a third and a half of all alcohol (Lemmens 2001) and is responsible for most of the external costs of drinking. ${ }^{34}$ Apparently, the volume of alcohol consumption, the frequency of drinking, and the frequency and volume of binge drinking all independently increase the risk of harm and violence (Wells et al. 2005). In short, acute consumption gives rise to significant external costs.

Indeed, there appears to be a relationship between the overall per-adult alcohol consumption and the number of individuals in a population with alcohol use disorders (Academy of Medical Sciences 2004). Rose and Day (2001) report a very high correlation between mean consumption and the prevalence of heavy drinking across

\footnotetext{
${ }^{33}$ The price derivative takes into account both the (uncompensated) price responsiveness of each consumer and his consumption level. Standardizing the price derivative makes the excise duty dependent on the relative price responsiveness of the consumer and his relative initial consumption.

${ }^{34}$ In the US, the top $2.5 \%$ of drinkers consume around a quarter of the total consumption, and the top $30 \%$ of drinkers account for nearly all (85-90\%) of the alcohol drunk (Greenfield and Rogers 1999). See also Cook and Moore (2002), who report that heavy and alcohol-dependent drinkers in the US (i.e. those in the top decile of the drinking distribution) consume more than half of all alcohol sold and are responsible for most of the external costs associated with harmful alcohol use.
} 
32 countries. ${ }^{35}$ An explanation may be that people affect and are affected by the drinking behavior of people around them, so that drinking levels 'spread like waves in water' through a society (Skog 2001), a hypothesis that goes by the name of the theory of collective consumption. This theory does not have a high standing among economists, but perhaps it should not be dismissed too lightly.

The long-term externalities of chronic alcohol use-small in comparison with the costs of acute consumption-consist mainly of health costs and should be calculated net of the long-term beneficial effects of moderate alcohol use. The relationship between chronic alcohol consumption and health damage has been depicted by a J-shaped curve: no drink is not very healthy, up to two drinks per day keeps the doctor away, but more than two drinks entails sharply diminishing health prospects. It seems that this J-shaped curve can also be drawn for the population as a whole if, as seems plausible, it is assumed that the risks of harmful alcohol use increase with average consumption. ${ }^{36}$

\subsection{Price elasticities of demand}

Price elasticities of demand for drinking are key determinants of the optimal alcohol excise duty. As regards the general demand for drinking, Smith (2005) reviews various US studies that capitalize on the variation of tax-price differentials between states to estimate demand elasticities. One of the most widely cited studies, by Leung and Phelps (1993), concludes that the price elasticities of alcohol demand are -0.3 for beer, -1.0 for wine and -1.5 for spirits. Clements et al. (1997) report price elasticities for seven countries (including three EU member states, i.e. Finland, Sweden and the UK), covering the period from the mid-1950s to the mid-1980s. They find elasticities of -0.35 for beer, -0.68 for wine and -0.98 for spirits, which are broadly in line with those found for the US. Interestingly, the price elasticities for different member states indicate that demand for alcoholic drinks is more sensitive to price in northern states than in southern states.

Of course, the relative price elasticities of demand for heavy and moderate drinking are of greater interest for determining the optimal alcohol excise duty. ${ }^{37}$ Intuitively, moderate drinkers should be more price responsive than heavy drinkers. Indeed, Manning et al. (1995) found that the median drinker had a price elasticity of -1.19 , whereas light and heavy drinkers' price elasticities were around -0.5 . Specifically, the price elasticity of the heaviest drinkers (those in the 95th percentile) was found to be not significantly different from zero. At the 80th percentile, however,

\footnotetext{
${ }^{35}$ When looking at the average drinker (the median) rather than the average of all drinkers (the mean), there is a reduced but still very strong relationship $(r>0.7)$ between average and heavy drinkers (Colhoun et al. 1997).

${ }^{36}$ However, Johansen et al. (2005) have produced evidence that the relationship between alcohol use and health is linear if abstainers are excluded from the analysis, suggesting that, on average, abstainers are not as healthy as moderate drinkers.

${ }^{37}$ Of course, changes in alcohol consumption are determined not only by changes in price but also by changes in income as expressed by income or expenditure elasticities. Leppänen et al. (2001) estimate the income elasticities (adjusted for purchasing power) of alcohol demand for 14 EU Member States. The income elasticities, which range from 0.4 in Denmark to 1.2 in Sweden, indicate that consumers view alcoholic drinks as normal goods, not luxuries.
} 
drinkers were still significantly responsive to price, with a price elasticity of -0.74 . In a recent study, Farrell et al. (2003) argue that higher duties would reduce alcohol dependence and abuse, estimating a high price elasticity of -1.487 . This confirms the results of an earlier study by Kenkel (1993), who estimated the demand for heavy drinking to be at least as price elastic as the demand for moderate drinking. While the overall picture is clearly complex (most studies show considerable variations), these findings suggest that there is scope for alcohol excise taxation to improve social welfare.

Furthermore, excise-induced price increases seem to be more effective in reducing the alcohol intake of young people than of older people. ${ }^{38}$ Young people are particularly vulnerable to harmful alcohol use, which often starts with 'alcopops' (alcoholic drinks mixed with non-alcoholic beverages), which can contribute both to heavier drinking and to a younger age of onset of drinking. Apparently, the additional excise duties on 'alcopops' in Denmark, France, Germany and Luxembourg (see Table 1) have greatly reduced their consumption by the young without a noticeable substitution of other drinks (Bundesministerium der Finanzen 2005). 'Alcopop' taxes are also being considered in the Netherlands and Sweden.

In the US, information on price elasticities of demand for alcohol and the variation in excises across US states has created a veritable cottage industry of research devoted to relating differences in taxes on alcoholic drinks to a wide variety of changes in social conditions. Table 8 provides a sample of these studies. They invariably report substantial reductions in alcohol-related external costs from (excise-induced) increases in the price of alcohol.

\subsection{Duty rate considerations}

As a first approximation, the average Pigouvian duty can be calculated as the total net external costs of harmful alcohol use divided by the number of liters of pure alcohol consumed (subsequently, appropriately divided over beer, wine and spirits). Unfortunately, the marginal duty is much more difficult to compute, because the relationship between alcohol consumption and external costs seems far from linear. ${ }^{39}$ The marginal duty rate would be considerably higher than the average duty rate if the external damage caused by alcohol consumption varied across units consumed by each individual. Applying an average tax rate means that the external costs generated by harmful users are compensated at the cost of reducing the consumer satisfaction of non-harmful users that is not regained as excise revenue (Pogue and Sgontz 1989).

\footnotetext{
${ }^{38}$ Grossman et al. (1998) have estimated the demand among individuals between the ages of 17 and 29 the age-group in which the prevalence of alcohol dependence and harmful use is highest. They report significant and numerically large linkages among past, present and future consumption. Also, the long-run elasticity of alcohol demand of -0.65 is $60 \%$ higher than the comparable short-run elasticity.

${ }^{39}$ It should be noted that in a second-best world the optimal excise on an externality-generating good does not exactly equal the marginal external costs. Afterall, the Sandmo (1976) formula applies in which the optimal tax equals the Ramsey term (which increases in the marginal cost function) and the Pigouvian term (which decreases). Nevertheless, a large number of exceptions are possible as indicated by the doubledividend literature (Bovenberg and de Mooij 1994). On balance, therefore, the Pigouvian approach seems an acceptable first approximation.
} 
Table 8 Effects of changes in alcohol excise duties in the United States, various years

Author(s) Year Content of study findings

\section{A. Harm to children}

Markowitz and 1999

Grossman

Grossman et al.

1994

\section{B. Drink-driving}

Ruhm

1996

Kenkel

Chaloupka,

Saffer, and

Grossman

\section{Crime and violence}

Markovitz

Cook and Moore

Markovitz

\section{Mortality and health}

$\begin{array}{ll}\text { Williams, } & 2002 \\ \text { Chaloupka, and } & \\ \text { Wechsler } & \\ \text { Harrison and } & 2000 \\ \text { Kassler } & \end{array}$

Grossman et al. 1994
A $10 \%$ increase in the beer excise duty would reduce severe domestic violence against children by $2.2 \%$

Raising the beer excise to the alcohol-equivalent excise on distilled spirits would reduce the drinking of under-age drinkers who drink frequently by $32 \%$

A $78 \%$ increase in the beer excise (restoring the real rate to its 1975 level) would reduce highway fatalities by $7-8 \%$

A $10 \%$ increase in the price of alcohol would decrease drunk-driving by $7.4 \%$ for men and $8.1 \%$ for women; the impact on under-age drinkers would be larger

A policy adjusting the US beer excise for the inflation rate since 1951 to the mid-1980s would have reduced total road traffic fatalities by $11.5 \%$ and fatalities among 18 - to 20 -year-olds by $32.1 \%$

A $1 \%$ increase in the price of alcohol decreases the rate of wife abuse by $3.1-3.5 \%$ but has no effect on abuse of husbands

A $10 \%$ increase in the beer excise would reduce rape by $1.32 \%$, robbery by $0.9 \%$, murder by $0.3 \%$ and assaults by $0.3 \%$

A $10 \%$ increase in the number of outlets that sell alcohol increases the probability of rape by almost $20 \%$

College students faced with a US $\$ 1.00$ increase in the average real price of a drink would be $33 \%$ less likely to make the transition from being a moderate drinker to a binge drinker

A US\$0.20 per six-pack increase in the beer excise would reduce the overall gonorrhoea rate by $8.9 \%$

A $10 \%$ increase in the price of beer reduces the number of high-school students who engage in binge drinking by $2-5 \%$

As noted above, however, nearly all external costs are caused by $10 \%$ of the drinking population who consume one-third to one-half of all alcohol sold. Perhaps this suggests that differences in external costs arise from differences between individuals rather than between units of alcohol consumed by a particular individual. This provides some support, as Diamond (1973) argues, for regarding the average external costs as a rough-and-ready indicator of the optimal externality duty. Admittedly, for harmful users of alcohol (almost 1 in 5 of all drinkers), the excise revenue collected will generally be less than the externalities they impose. However, the harmful users will have a heavier weighting in the optimal uniform duty, because they have a higher initial consumption. Accordingly, given the same elasticity, the excise-induced change in their absolute consumption will be greater than the change in the absolute consumption of moderate drinkers. The reverse is true for moderate drinkers. The excise duty collected from them will exceed the externality, if any, they impose. 
Apart from implications for the level of the duty on alcohol, there are also consequences for the pattern of duties on various kinds of alcohol. As Table 1 indicates, on average, spirits are taxed twice as heavily as beer per unit of alcohol and five times more heavily than wine. Prima facie, this suggests that there is a case for increasing the wine and beer duties relative to the spirits duty (Saffer and Chaloupka 1994).

\section{Alcohol regulation}

Invariably, excise taxation goes hand in hand with regulation. In the case of tobacco, the regulations are straightforward-no smoking in public places, no advertisements - but in the area of alcoholic drinking, a more multifaceted approach is common. Besides taxation and pricing, the approach includes regulating the physical availability of alcohol, drink-driving counter-measures, altering the drinking context, treatment and early intervention, regulating alcohol promotion, and education and persuasion programmes. These (complementary) regulations are aimed at reducing the externalities associated with alcohol consumption and have a 'dutyequivalent' effect which, in theory, should be deducted from the Pigouvian tax that would be set in the absence of the regulatory policies. Again, the trade-off with the welfare loss suffered by moderate drinkers should be considered.

Nearly all member states have minimum legal purchase ages (MPAs) of 16 years (southern EU) or 18 years (northern EU) regarding the sale of beer, wine and spirits in bars and shops. Kenkel (1993) has shown that MPAs reduce the highway fatality rate for the affected age-groups by about $7 \%$. Random breath testing (RBT) and lowered blood alcohol concentration (BAC) limits for young drivers (typically, 40$50 \mathrm{mg} \%$ but $0 \mathrm{mg} \%$ in the Czech Republic, Hungary and the Slovak Republic) are common throughout the EU. Half of all member states have legal sale restrictions on the places of sale of alcoholic drinks, but few on the hours and days of sale (WHO 2006). Finland and Sweden operate off-premise retail alcohol monopolies (upheld by the ECJ), which tend to reduce outlet density and thus alcohol sales. These measures, however, reduce the welfare of risk-free drinkers, which is not even offset by any excise revenues. This is also the case with the partial to complete mandatory or voluntary restrictions on advertising, sponsorship or brand identification.

Table 9, reproduced from Babor et al. (2003), shows how effective these and other strategies or interventions are in reducing alcohol harm, regardless of the cost of implementing them and the reduction in welfare of moderate drinkers. Targeted measures, such as regulations on the physical availability of alcohol and drink-driving counter-measures, prove to be highly effective. Twenty-three studies of random and selective breath testing found a decline of 22\% (range 13-36\%) in fatal car crashes (Shults et al. 2001). Furthermore, a review of 46 studies on licence suspension in the US showed that suspension was followed by an average reduction of $5 \%$ in alcoholrelated accidents and a reduction of $26 \%$ in fatal accidents (Zobeck and Williams 1994).$^{40}$ By contrast, the effectiveness of designated drivers, voluntary codes of bar

\footnotetext{
${ }^{40}$ Alcohol locks on cars are one of the newest measures to curtail drink-driving (Mathijssen 2005). In the Netherlands, a target group of DWI (Driving While Intoxicated) offenders has been selected for a trial run of alcolocks. Based on an estimated 65\% reduced crash rate for alcolock users, the estimated benefit of the 
Table 9 Effectiveness of restraining harmful alcohol use through regulatory measures

Strategy or intervention

Effectiveness

$+++=$ highest

$0=$ not effective

$?=$ unknown

\section{Regulating physical availability}

Minimum legal purchase age

$$
\begin{aligned}
& +++ \\
& +++ \\
& +++ \\
& ++ \\
& ++
\end{aligned}
$$

Server legal liability

Restrictions on density of outlets

\section{Drink-driving counter-measures}

Random breath testing (RBT)

Lowered BAC ${ }^{\mathrm{a}}$ limits

$$
\begin{aligned}
& +++ \\
& +++ \\
& +++ \\
& ++ \\
& 0
\end{aligned}
$$

Administrative license suspension

\section{Altering the drinking context}

Outlet policy to not serve intoxicated persons

Enforcement of on-premise regulations

Training bar staff to manage aggression

$$
\begin{aligned}
& ++ \\
& ++ \\
& + \\
& 0 \\
& 0
\end{aligned}
$$

Voluntary codes of bar practice

Promoting alcohol-free activities

\section{Treatment and early intervention}

Brief intervention with at-risk drinkers

$$
\begin{aligned}
& ++ \\
& + \\
& + \\
& + \\
& \\
& + \\
& ?
\end{aligned}
$$

Alcohol problems treatment

Mutual help/self-help attendance

Mandatory treatment of repeat drinking-drivers

\section{Regulating alcohol promotion}

Advertising bans

Advertising content controls

\section{Education and persuasion}

Alcohol education in schools $\quad 0$

College student education $\quad 0$

$\begin{array}{ll}\text { Public services messages } & 0\end{array}$

Warning labels $\quad 0$

\section{Source}

Based on Babor et al. (2003), downloaded from www.ias.org.uk (IAS Fact Sheet, 'Alcohol Policies', 21 July 2005)

Note

${ }^{\mathrm{a}}$ Blood alcohol content 
practice and various forms of education and persuasion is low. Advertising bans are not very effective, although there is some evidence that alcohol advertising is influential in positively shaping young people's attitudes and perceptions about alcohol (Fleming et al. 2004).

Regulatory measures carry a monetary cost, however, which differs from one measure to the next. Indeed, it is the cost-effectiveness of the various strategies that is of greatest interest from an economic point of view. In a recent study, Chisholm et al. (2004) calculate that in countries with high levels of hazardous consumption (more than $5 \%$ of all drinkers), such as the UK and other northern EU member states (see Table 3), both individual interventions by doctors (especially if targeted at $25 \%$ of the at-risk population in a primary-care setting) and population-wide interventions such as alcohol excises (even after allowing for an estimated 10-15\% increase in illicit production or smuggling) can have significant impact on harmful alcohol consumption at the population level.

Beyond that, reduced access to alcohol (in public buildings, work places, at sporting events, etc.), random breath testing, and lower BAC limits for young or professional drivers are highly cost-effective strategies. Her et al. (1999) find that the lower the outlet density, the lower consumption and alcohol-related problems will be. Wagenaar and Toomey (2000) document that changes in minimum drinking age laws can have substantial effect on youth drinking and alcohol-related harm, particularly road traffic accidents. Reviews have found that lower BAC limits for young drivers reduce fatal crashes by between $9 \%$ and $24 \%$ (Shults et al. 2001). By contrast, designated drivers-e.g. BOB, the non-drinking driver in Belgium and the Netherlands-seem to have little effect and may even be harmful by suggesting that everyone in the car can be stone drunk as long as the driver is sober. Indeed, several studies indicate an increase in passenger alcohol consumption when a designated driver is available. Harding and Caudill (1997), for example, estimate that the mean increase in the BACs of passengers of designated drivers was $0.17 \mathrm{~g} / \mathrm{l}$, with young and high-risk drinkers particularly likely to increase consumption.

Overall, individual approaches to prevention are shown to have a much smaller effect on drinking patterns and problems than do population-based approaches that affect the drinking environment and the price and availability of alcoholic drinks. Like other methodologies used in public health studies, however, the DALY approach fails to make the distinction between internal and external costs. Even if taxation and regulation are effective, it does not necessarily follow that the benefits of taxation are greater than the costs.

\section{Implications for the EU's alcohol tax policy}

This paper has shown that harmful alcohol use is an important health and safety issue in the EU. European adults on average drink twice as much as might accord with a healthy lifestyle. Much domestic violence, many accidents and a large part of crime are alcohol-related. Drinking is a habit that starts at an ever younger age, although

program is an annual reduction of four or five fatalities at an annual program cost of $€ 0.9$ million ( $€ 2,200$ per lock). 
there is a clear public stake in keeping minors away from alcohol and in preventing alcohol-induced child abuse and neglect, and fetal damage.

Economic theory prescribes that the external costs of harmful alcohol use should be internalized in price, among others through excise taxation. In the main, the external costs are a function of the frequency and volume of alcohol consumption. This means that they differ from one drinker to another. While moderate drinkers may derive health and social benefits from alcohol consumption, heavy drinkers cause most of the external costs. For lack of information, however, it is not possible to differentiate alcohol excise duties on the basis of the kind of drinker and his drinking habits. However, the level of the uniform Pigouvian duty that has to be imposed can be inferred from information on drinking patterns and volume, the shape of the damage function, the total level and pattern of the external costs, and the price responsiveness of drinkers. This permits an assessment of the gain from a reduction in external costs caused by heavy drinkers relative to the loss in consumption benefits of moderate drinkers.

Ten per cent of all drinkers consume one-third to one-half of all alcohol sold and are responsible for most of the external costs. While there are no explicit external cost studies of harmful alcohol use in the EU, the external costs can be inferred from social cost studies. The tangible costs of heavy drinking are high in most member states; apparently, heavy drinkers do not pay their way. An analysis of a social cost study for the UK indicates that alcohol excise duty collections do not cover the tangible costs of harmful alcohol use, narrowly defined. This is certainly the case in many other member states with similar drinking patterns but lower alcohol excise duties. Presumably, higher excises would reduce overall consumption as well as harmful alcohol use, particularly by young people. ${ }^{41}$ Clearly, more can be done to align the excise duties on beer, wine and spirits in line with alcohol content.

The excise taxation of alcohol is a fairly blunt instrument, causing welfare losses to non-harmful users while at the same time not adequately controlling the drinking of harmful users. The use of the excise duty instrument in reducing external costs should be complemented, therefore, by regulatory measures aimed at specific problem groups, such as young drinkers and alcohol-dependent drinking. To the extent that this can be done, it reduces the need for externality taxation. Cost-effective measures that will have a noticeable impact on harmful alcohol use include reduced access to alcohol in public buildings, work places and at sporting events, and drinkdriving tests. A lower limit of $0.2 \mathrm{~g} / \mathrm{l}$ or less should be considered for young drivers. Differentially higher excise duties on 'alcopops' appear to reduce youth drinking.

There is a case for narrowing differences in alcohol taxes between EU member states by significantly increasing the agreed EU-wide floors to alcohol taxes. This would reduce the economic and fiscal costs associated with (legitimate) cross-border shopping, which, like other tax avoidance activities, involves a deadweight resource

\footnotetext{
${ }^{41}$ It is often argued that the output, income and employment generated by the alcohol industry (some $2 \frac{1}{2}$ million people are employed in alcohol production and distribution in the EU-see Naert et al. 2001) must be viewed as benefits to the community at large, but this proposition rests on the unlikely assumption that, in the absence of drinking, the money spent on alcohol would not be spent on other products and that the resources used in producing and distributing alcohol would have no alternative uses. This having been said, short-run adjustment costs from industry downsizing would arise, of course.
} 
cost, incurred in the pursuit of a transfer payment, the tax saving. Approximation of duty rates might be difficult, however, in view of the zero duty on wine in many member states in combination with the maintenance of an approximate alcohol-duty relationship between wine, beer and spirits. Also, agreement is unlikely to be promoted by the Commission's proposal to further liberalize intra-EU alcohol transfers by allowing consumers to buy non-commercially at distance.

Over the years, EU member states have come closer together in alcohol consumption levels, drink preferences and youth drunkenness. Accordingly, harmful alcohol use is more of a common problem than it used to be. This suggests that a common reflection on measures to tackle the issues is called for. The economic approach, with its fundamental notion that tradeoffs have to be made, offers a useful, if difficult, guide for the design of an alcohol policy. The central insight is: the EU is never going "to solve the alcohol problem", but it can probably craft better policies by recognizing the tradeoffs.

Acknowledgements The author is grateful to Vidar Christiansen, Peter Kooiman and Stephen Smith for their comments on a preliminary version of this paper, which was presented at the CESifo conference on public economics held in Munich, 21-23 April 2006. The penultimate version of the paper was discussed at the 62nd Congress of the International Institute of Public Finance held in Paphos, Cyprus, 28-31 August 2006. Subsequently, helpful comments were received from Ruud de Mooij and Daniël van Vuuren at CPB, and from two anonymous referees. Judith Payne applied the finishing touch.

\section{References}

Academy of Medical Sciences. (2004). Calling time: the nation's drinking as a major public health issue. www.acmedsci.ac.uk.

Anderson, P., \& Baumberg, B. (2006). Alcohol in Europe. London: Institute of Alcohol Studies.

Aspect Consortium. (2004). Tobacco or health in the European Union: past, present and future. Brussels: European Commission.

Babor, T. F., Caetano, R., Casswell, S., Edwards, G., Giesbrecht, N., Graham, K., Grube, J., Gruenewald, P., Hill, L., Holder, H., Homel, R., Österberg, E., Rehm, E. J., \& Rossow, I. (2003). Alcohol: no ordinary commodity - research and public policy. Oxford: Oxford University Press.

Barker, F. (2002). Consumption externalities and the role of government: the case of alcohol. New Zealand Treasury, Working Paper 02/25, www.treasury.govt.nz/workingpapers/2002/02-25.asp.

Bergmann, E., \& Horch, K. (2002). Kosten Alkoholassozierter Krankheiten: Schätzung für Deutschland. Berlin: Robert Koch Institut.

Bird, R., \& Wallace, S. (2006). Taxing alcohol: reflections from international experience. In S. Cnossen (Ed.), Excise tax policy and administration in Southern African countries. Pretoria: UNISA Press.

Bonomo, Y. A., Bowes, G., Coffey, C., Carlin, J. B., \& Patton, G. C. (2004). Teenage drinking and the onset of alcohol dependence: a cohort study over seven years. Addiction, 99(12), 1520-1528.

Bovenberg, A. L., \& de Mooij, R. (1994). Environmental levies and distortionarz taxation. American Economic Review, 84, 1085-1089.

Brand, S., \& Price, R. (2000). The economic and social costs of crime. Home Office Research Study 217, London.

Bundesministerium der Finanzen. (2005). Bericht der Bundesregierung über die Auswirkungen des Alkopopsteuergesetzes auf den Alkoholkonsum von Jugendlichen unter 18 Jahren sowie die Marktentwicklung von Alkopops und vergleichbaren Getränken. www.bmg.bund.de/nn_604822/SharedDocs/ Download/DE/Presse/Pressemitteilungen/Presse-Drogenbeauftragte-2005/pdf-Alkopopsteuerberichtpdf,templateId=raw,property=publicationFile.pdf/pdf-Alkopopsteuerbericht-pdf.pdf.

Byrne, S. (2005). The cost of alcohol-related problems in Ireland. Dublin: Institute of Technology.

Caetano, R., \& Cunradi, C. (2002). Alcohol dependence: a public health perspective. Addiction, 97(7), $633-645$

Callingham, M. (2002). National Association for Children of Alcoholics (NACOA) survey: initial findings. www.nacoa.org.uk/pdf/Summary_of_Callingham_research.pdf. 
Chaloupka, F. J., Saffer, H., \& Grossman, M. (1993). Alcohol-control policies and motor-vehicle fatalities. Journal of Legal Studies, 22, 161-186.

Chisholm, D., Rehm, J., van Ommeren, M., \& Monteiro, M. (2004). Reducing the global burden of hazardous alcohol use: a comparative cost-effectiveness analysis. Journal of Studies in Alcohol, 65, 782793.

Christiansen, V., \& Smith, S. (2001). The economics of duty-free shopping. CESifo, Working Paper 595.

Clements, K. W., Yang, W., \& Zheng, S. W. (1997). Is utility addictive? The case of alcohol. Applied Econometrics, 29(9), 1163-1167.

Colhoun, H., Ben-Shlomo, Y., Dong, W., Bost, L., \& Marmot, M. (1997). Ecological analysis of collectivity of alcohol consumption in England: importance of average drinker. British Medical Journal, 314, 1164. bmj.bmjjournals.com/cgi/content/full/314/7088/1164.

Collicelli, C. (1996). Income from alcohol and the costs of alcoholism. Alcologia, 8(2), 135-143.

Collins, D., \& Lapsley, H. (2002). Counting the cost: estimates of the social costs of drug abuse in Australia in 1998-1999. Canberra: Australian Government Printing Service.

Cook, C. H., \& Gurling, H. D. (2001). Genetic predisposition to alcohol dependence and problems. In N. Heather, T. J. Peters, \& T. Stockwell (Eds.), International handbook of alcohol problems and dependence. West Sussex: Wiley.

Cook, P. J., \& Moore, M. J. (1993). Economic perspectives on reducing alcohol-related violence. In Alcohol and interpersonal violence: fostering multidisciplinary perspectives Research monograph (Vol. 24). Bethesda: National Institute on Alcohol Abuse and Alcoholism.

Cook, P. J., \& Moore, M. J. (2002). The economics of alcohol abuse and alcohol-control policies. Health Affairs, 21(2), 120-133.

Corrao, G., Luca, R., Bagnardi, V., Zambon, A., \& Poikolainen, K. (2000). Alcohol and coronary heart disease: a meta-analysis. Addiction, 95(10), 1505-1523.

Crawford, I., Smith, Z., \& Tanner, S. (1999). Alcohol taxes, tax revenues and the Single European Market. Fiscal Studies, 20(3), 287-304.

Crooks, E. (1989). Alcohol consumption and taxation (Report 34). Institute for Fiscal Studies, London.

Devlin, N. J., Scuffham, P. A., \& Bunt, L. J. (1997). The social costs of alcohol abuse in New Zealand. Addiction, 92(11), 1491-1505.

Diamond, P. (1973). Consumption externalities and imperfect corrective pricing. Bell Journal of Economics, 4(2), 526-538.

Elinder, L. S., Joossens, L., Raw, M., Andréasson, S., \& Lang, T. (2003). Public health aspects of the EU common agricultural policy: developments and recommendations for change in four sectors (fruit and vegetables, dairy, wine and tobacco). Stockholm: National Institute for Public Health. www.fhi.se/ upload/PDF/2004/English/eu_inlaga.pdf.

English, D. R., Holman, C. D., Milne, E., Winter, M. J., Hulse, G. K., Codde, G., Bower, C. I., Cortu, B., de Klerk, N., Lewin, G. F., Knuiman, M., Kurinczuk, J. J., \& Ryan, G. A. (1995). The quantification of drug caused morbidity and mortality in Australia. Canberra: Commonwealth Department of Human Services and Health.

ETSC-European Transport Safety Council. (2003). Cost-effective EU transport safety measures. Brussels. www.etsc.be/documents/costeff.pdf.

Eurobarometer. (2003). Health, food and alcohol and safety. Brussels: European Commission.

European Commission. (2004). Report from the Commission to the Council. The European Parliament and the European Economic and Social Committee on the Rates of Excise Duty Applied on Alcohol and Alcoholic Beverages, COM(2004) 223 final, Brussels.

Farrell, S., Manning, W. G., \& Finch, M. D. (2003). Alcohol dependence and the price of alcoholic beverages. Journal of Health Economics, 22(1), 117-147.

Fenoglio, P., Parel, V., \& Kopp, P. (2003). The social cost of alcohol, tobacco and illicit drugs in France, 1997. European Addiction Research, 9(1), 18-28.

Fleming, K., Thorson, E., \& Atkin, C. K. (2004). Alcohol advertising exposure and perceptions: links with alcohol expectancies and intentions to drink or drinking in underaged youth and young adults. Journal of Health Communication, 9(1), 3-29.

Garcia-Sempere, A., \& Portella, E. (2002). Los estudios del coste del alcoholismo: marco conceptual, limitaciones y resultados en España. Addiciones, 14(1), 141-153.

Greenfield, T. K., \& Rogers, J. D. (1999). Who drinks most of the alcohol in the U.S.? The policy implications. Journal of Studies on Alcohol, 60, 78-89.

Grossman, M., Chaloupka, F. J., Saffer, H., \& Laixuthai, A. (1994). Effects of alcohol price policy on youth: a summary of economic research. Journal of Research on Adolescence, 4(2), 347-364.

Grossman, M., Chaloupka, F., \& Sirtalan, I. (1998). An empirical analysis of alcohol addiction: results from the Monitoring the Future panels. Economic Inquiry, 36, 39-48. 
Gruber, J., \& Koszegi, B. (2001). Is addiction "rational”? Theory and evidence. Quarterly Journal of Economics, 116, 1261-1303.

Harding, W. M., \& Caudill, B. D. (1997). Does the use of designated drivers promote excessive alcohol consumption? In C. Mercier-Guyon (Ed.), Proceedings of the 14th annual conference on alcohol, drugs and traffic safety (Vol. 3). Annecy: Centre d'Études et de Recherches en Médicine du Trafic.

Harrison, P., \& Kassler, W. J. (2000). Alcohol policy and sexually transmitted disease rates-United States, 1982-1995. US Department of Health and Human Services, Center for Disease Control, Epidemiology Program Office. MMWR Weekly, 49(16), 364-369.

Harwood, P. (2000). Updating estimates of the economic costs of alcohol abuse in the United States: update methods, and data. Report prepared by the Lewin Group for the National Institute on Alcohol Abuse and Alcoholism.

Her, M., Giesbrecht, N., Room, R., \& Rehm, J. (1999). Privatizing alcohol sales and alcohol consumption: evidence and implications. Addiction, 94(8), 1125-1139.

Hibell, B., Andersson, B., Bjarnason, T., Ahlström, S., Balakireva, O., Kokkevi, A., \& Morgan, M. (2004). The ESPAD report 2003: alcohol and other drug use among students in 35 European countries. Stockholm: Swedish Council for Information on Alcohol and Other Drugs (CAN) and the Pompidou Group at the Council of Europe. www.espad.org.

High Level Group on Fraud in the Tobacco and Alcohol Sectors. (1998). Report to Directors General for customs and indirect taxation. ec.europa.eu/taxation_customs/resources/documents/taxation/excise_ duties/circulation_control/studies_reports/Tobacco_and_alcohol_fraud_report_en.pdf.

HM Customs and Excise. (2004). Measuring and tackling indirect tax losses-2004. London: HMSO. customs.hmrc.gov.uk/channelsPortalWebApp/channelsPortalWebApp.portal?_nfpb=true\&_ pageLabel=pageVAT_ShowContent\&propertyType=document\&columns=1\&id=HMCE_PROD_ 011582

Huang, C. D. (2003). Econometric models of alcohol demand in the United Kingdom. Government Economic Service, Working Paper 140. customs.hmrc.gov.uk/channelsPortalWebApp/ channelsPortalWebApp.portal?_nfpb=true\&_pageLabel=pageExcise_ShowContent\&id=HMCE_ PROD_008459\&propertyType=document.

IAS-Institute of Alcohol Studies. (2003). Economic costs and benefits. IAS Fact Sheet, 14 November.

Johansen, D., Gronbaek, M., Overvad, K., Schnohr, P., \& Andersen, P.-K. (2005). Generalized additive models applied to analysis of the relation between amount and type of alcohol and all-cause mortality. European Journal of Epidemiology, 20(1), 29-36.

Karlsson, T., \& Tigerstedt, C. (2005). Alcohol policy: changing climate and changing structures in the Nordic countries. Presentation at Alcohol-Use, Harms and Policy, a research-based Nordic-Baltic Seminar, Riga, 3 October.

Kenkel, D. S. (1993). Drinking, driving and deterrence: the effectiveness and social cost of alternative policies. Journal of Law and Economics, 26(2), 877-913.

Kenkel, D. S. (1996). New estimates of the optimal tax on alcohol. Economic Inquiry, 34, 296-319.

KPMG. (2001). Excessive alcohol consumption in the Netherlands: trends and social costs. Hoofddorp: KPMG Economic Consulting.

Leifman, H. (2001). Estimations of unrecorded alcohol consumption levels and trends in 14 European countries. Nordisk Alkohol- \& Narkotikatidskrift, 18, 54-70.

Lemmens, P. (2001). Relationship of alcohol consumption and alcohol problems at the population level. In H. Heather, T. J. Peters, \& T. Stockwell (Eds.), International handbook of alcohol dependence and problems. New York: Wiley.

Leppänen, K., Sullström, R., \& Suoniemi, I. (2001). Effects of economic factors on alcohol consumption in 14 European countries. Nordic Studies on Alcohol and Drugs, 18, 100-116.

Leung, S., \& Phelps, C. (1993). My kingdom for a drink ...? A review of estimates of the price sensitivity of alcoholic beverages. In M. E. Hilton, \& G. Bloss (Eds.), Economics and the prevention of alcoholrelated problems (NIH Publication 93-3513). National Institutes of Health, Rockville, MD.

Lieber, C. S. (2003). Alcohol and health: a drink a day won't keep the doctor away. Cleveland Clinic Journal of Medicine, 70(11), 945-953.

Lima, E., \& Esquedro, T. (2003). The economic costs of alcohol misuse in Portugal. Universidade do Minho, Nucleo de Investigaçao em Microeconomica Alicada, Working Paper 24.

MacDonald, Z., \& Shields, M. A. (2001). The impact of alcohol consumption on occupational attainment in England. Economica, 68(271), 427-453.

Manning, W. G., Blumberg, L., \& Moulton, L. H. (1995). The demand for alcohol: the differential response to price. Journal of Health Economics, 14, 123-148.

Manning, W. G., Keeler, E. B., Newhouse, J. P., Sloss, E. M., \& Wasserman, J. (1989). The taxes of sin: do smokers and drinkers pay their way? Journal of the American Medical Association, 261, 1604-1609. 
Markowitz, S. (1999). The price of alcohol, wife abuse, and husband abuse. National Bureau of Economic Research, Working Paper 6916.

Markowitz, S. (2000). An economic analysis of alcohol, drugs, and violent crime in the National Crime Victimization Survey. National Bureau of Economic Research, Working Paper 7982.

Markowitz, S., \& Grossman, M. (1999). Alcohol regulation and domestic violence towards children. Contemporary Economic Policy, 16(3), 309-321.

Mathijssen, R. (2005). An alcohol interlock program. Ottawa: Traffic Injury Research Foundation.

Matthews, S., \& Richardson, S. (2005). Findings from the 2003 offending, crime and justice survey: alcohol-related crime and disorder (Home Office Findings 261). London, www.homeoffice.gov.uk/ rds/pdfs05/r261.pdf.

Maynard, A., Godfrey, C., \& Hardman, G. (1994). Conceptual issues in estimating the social costs of alcohol. Paper prepared for an international symposium on the Economic Costs of Substance Abuse, Banff, Canada, 11-13 May 1994, www.ccsa.ca/pdf/ccsa-005409-1994.pdf.

Miller, T. R., \& Blincoe, L. J. (1994). Incidence and costs of alcohol-involved crashes in the United States. Accident Analysis and Prevention, 26(5), 583-592.

Mirrlees-Black, C. (1999). Domestic violence: findings from a new British crime survey self-completion questionnaire (Home Office Research Study 191). Home Office, London.

Naert, P., Naert, S., \& Maex, D. (2001). The socio-economic impact of the European alcoholic beverages industry. In The Amsterdam Group report 2001: alcoholic beverages and European Society, TAG.

NIAAA - National Institute on Alcohol Abuse and Alcoholism. (2000). Tenth special report to the US Congress on alcohol and health. Washington: US Government Printing Office.

OECD_Organization for Economic Cooperation and Development. (2005). Revenue statistics 19652003, Paris.

Pacolet, J., Degreef, T., \& Bouten, R. (2003). Sociale kosten-batenanalyse van alcoholgebruik en -misbruik in België. Leuven: KUL, Hoger instituut voor de arbeid.

Peck, R., Chaloupka, F. J., Jha, P., \& Lightwood, J. (2000). A welfare analysis of tobacco use. In P. Jha, \& F. Chaloupka (Eds.), Tobacco control in developing countries. Oxford: Oxford University Press on behalf of the World Bank and the World Health Organization.

Peele, S., \& Brodsky, A. (2000). Exploring psychological benefits associated with moderate alcohol use. Drug and Alcohol Dependence, 60, 221-247.

Pogue, T. F., \& Sgontz, L. G. (1989). Taxing to control social costs: the case of alcohol. American Economic Review, 79(1), 235-243.

Ramsey, F. (1927). A contribution to the theory of taxation. Economic Journal, 37, 47-61.

Ramstedt, M., \& Hope, A. (2003). The Irish drinking habits of 2002: drinking and drinking-related harma European comparison. Dublin: Department of Health and Children.

Rehm, J., Room, M., Monteiro, G., Gmel, K., Graham, N., Rehn, C., Sempos, T., Frick, U., \& Jernigan, D. (2004). Alcohol. In M. Ezzati, A. D. Lopez, A. Rodgers, \& C. J. L. Murray (Eds.), Comparative quantification of health risks: global and regional burden of disease due to selected major risk factors. Geneva: World Health Organization.

Rehn, N., Room, R., \& Edwards, G. (2001). Alcohol in the European region: consumption, harm and policies. Copenhagen: World Health Organization Regional Office for Europe.

Ridolfo, B., \& Stevenson, C. (2001). The quantification of drug-caused mortality and morbidity in Australia, 1998. Canberra: Australian Institute of Health and Welfare.

Rose, G., \& Day, S. (2001). The mean population predicts the number of deviant individuals. British Medical Journal, 301, 1031-1034.

Rossow, I., Pernanen, K., \& Rehm, J. (2001). Accidents, suicide and violence. In H. Klingemann, \& G. Gmel (Eds.), Mapping the social consequences of alcohol consumption. Dordrecht: Kluwer Academic.

Ruhm, C. J. (1996). Alcohol policies and highway vehicle fatalities. Journal of Health Economics, 15, 435-454.

Saffer, H., \& Chaloupka, F. J. (1994). Alcohol tax equalization and social costs. Eastern Economic Review, $20(1), 33-43$.

Salomaa, J. (1995). The costs of the detrimental effects of alcohol abuse have grown faster than alcohol consumption in Finland. Addiction, 90(4), 525-537.

Sandmo, A. (1976). Direct versus indirect Pigouvian taxation. European Economic Review, 7, 337-349.

Scottish Executive Health Department. (2003). Alcohol misuse in Scotland: trends and costs. Edinburgh: Catalyst Health Economics Consultants Ltd.

Settertobulte, W., Jensen, B. B., \& Hurrelman, K. (2001). Drinking among young Europeans. Copenhagen: WHO Regional Office for Europe. 
Shults, R. A., Elder, R. W., Sleet, D. A., Nicholas, J. L., Alao, M. O., Carande-Kulis, V. G., Zaza, S., Sosin, D. M., Thompson, R. S., \& the Task Force on Community Preventive Services. (2001). Reviews of evidence regarding interventions to reduce alcohol-impaired driving. American Journal of Preventive Medicine, 21, 66-88.

Single, E., Collins, D., Easton, B., Harwood, H., Lapsley, H., Kopp, O., \& Wilson, E. (2003). International guidelines for estimating the costs of substance abuse. Ottawa: Canadian Centre on Substance Abuse.

Single, E., \& Easton, B. (2001). Estimating the economic costs of alcohol misuse: why we should do it even though we shouldn't pay too much attention to the bottom-line results. Paper presented at Kettil Bruun Society for Social and Epidemiological Research on Alcohol, Toronto, www.eastonbh.ac.nz/ article107.html.

Single, E., Robson, L., \& Xie, X. (1996). The costs of substance abuse in Canada: a cost estimation study. Ottawa: Canadian Centre on Substance Abuse.

Skog, O.-J. (2001). Commentary on Gmel \& Rehm's interpretation of the theory of collectivity of drinking culture. Drug and Alcohol Review, 20(3), 325-331.

Smith, S. (2005). Economic issues in alcohol taxation. In S. Cnossen (Ed.), Theory and practice of excise taxation: smoking, drinking, gambling, polluting, and driving. Oxford: Oxford University Press.

Strategic Task Force on Alcohol. (2004). Interim report. Dublin: Department of Health and Children.

Sundhedsministeriet. (1999). De samfundsøkonomiske konsekvenser af alkoholforbrug (2nd ed.). Copenhagen: Ministry of Health. www.im.dk/publikationer/alkoholrapport/index.htm.

UK Cabinet Office. (2003). Alcohol misuse: how much does it cost? London: Strategy Unit. www.strategy. gov.uk/downloads/files/econ.pdf.

Wagenaar, A. C., \& Toomey, T. L. (2000). Alcohol policy: gaps between legislative action and current research. Contemporary Drug Problems, 27, 681-733.

Warner, K. E., Chaloupka, F. J., Cook, P. J., Manning, W. C., Newhouse, J. P., Novotny, T. E., Schelling, T. C., \& Townsend, J. (1995). Criteria for determining an optimal cigarette tax: the economist's perspective. Tobacco Control, 4, 380-386.

Watson, D., \& Parsons, J. (2005). Domestic abuse of women and men in Ireland: report on the National study of domestic abuse. Dublin: Stationery Office.

Wells, M., Gerrard, P., \& Hubbard, D. (2005). Oral evidence to the Treasury (Sub-)Committee on Excise Duty Fraud, 17 November 2004. In House of Commons Treasury Committee, excise duty fraud: fourth report of session 2004-2005 (pp. Ev1-Ev12). London: The Stationery Office.

Wells, S., Graham, K., Speechley, M., \& Koval, J. J. (2005). Drinking patterns, drinking contexts and alcohol-related aggression among late adolescent and young adult drinkers. Addiction, 100, 933-944.

White, H. R., Altmann, D. R., \& Nanchahal, K. (2002). Alcohol consumption and mortality: modelling risks for men and women at different ages. British Medical Journal, 325, 191-198.

WHO-World Health Organization. (2004). Global status report on alcohol. www.who.int/substance_ abuse/publications/global_status_report_2004_overview.pdf.

WHO-World Health Organization. (2005). Alcohol policy in the WHO European Region: current status and the way forward. Copenhagen and Bucharest: Regional Office for Europe.

WHO_-World Health Organization. (2006). Global alcohol database. www3.who.int/whosis/alcohol/ alcohol_about_us.cfm?path=whosis,alcohol,alcohol_about\&language=english.

Williams, J., Chaloupka, F. J., \& Wechsler, H. (2002). Are there differential effects of price and policy on college students' drinking intensity? National Bureau of Economic Research, Working Paper 8702.

World drink trends. (2004). NTC Publications, Henley on Thames.

Zobeck, T. S., \& Williams, G. D. (1994). Evaluation synthesis of the impact of DWI laws and enforcement methods: final report. Rockville: Office of Policy Analysis, National Institute on Alcohol Abuse and Alcoholism (NIAAA). 